Article

\title{
Essential Oils of Five Baccharis Species: Investigations on the Chemical Composition and Biological Activities
}

\author{
Jane M. Budel 1,2,*(D), Mei Wang ${ }^{2}\left(\mathbb{D}\right.$, Vijayasankar Raman ${ }^{2}$, Jianping Zhao ${ }^{2}$, Shabana I. Khan ${ }^{2}$, \\ Junaid U. Rehman ${ }^{2}$, Natascha Techen ${ }^{2}$ D, Babu Tekwani ${ }^{2}$, Luciane M. Monteiro ${ }^{1}$, \\ Gustavo Heiden ${ }^{3}{ }^{\mathbb{D}}$, Inês J. M. Takeda ${ }^{4}$, Paulo V. Farago ${ }^{1}$ and Ikhlas A. Khan ${ }^{2}$ \\ 1 Departamento de Ciências Farmacêuticas, Universidade Estadual de Ponta Grossa (UEPG), \\ Ponta Grossa, PR 84030-900, Brasil; lmmonteiro@hotmail.com (L.M.M.); pvfarago@gmail.com (P.V.F.) \\ 2 National Center for Natural Products Research, School of Pharmacy, University of Mississippi, \\ Mississippi, MS 38677, USA; meiwang@olemiss.edu (M.W.); vraman@olemiss.edu (V.R.); \\ jianping@olemiss.edu (J.Z.); skhan@olemiss.edu (S.I.K.); jurehman@olemiss.edu (J.U.R.); \\ ntechen@olemiss.edu (N.T.); btekwani@olemiss.edu (B.T.); ikhan@olemiss.edu (I.A.K.) \\ 3 Embrapa Clima Temperado, Pelotas, RS 70770-901, Brazil; gustavo.heiden@embrapa.br \\ 4 Departamento de Meio Ambiente, Universidade Estadual de Maringá (UEM), \\ Umuarama, PR 87020-900, Brazil; takedaines@bol.com.br \\ * Correspondence: janemanfron@hotmail.com; Tel.: +55-42-3220-3000
}

Academic Editors: Charles L. Cantrell and Muhammad Ilias

Received: 7 August 2018; Accepted: 10 October 2018; Published: 12 October 2018

\begin{abstract}
This paper provides a comparative account of the essential oil chemical composition and biological activities of five Brazilian species of Baccharis (Asteraceae), namely B. microdonta, B. pauciflosculosa, B. punctulata, B. reticularioides, and B. sphenophylla. The chemical compositions of three species (B. pauciflosculosa, B. reticularioides, and B. sphenophylla) are reported for the first time. Analyses by GC/MS showed notable differences in the essential oil compositions of the five species. $\alpha$-Pinene was observed in the highest concentration $(24.50 \%)$ in B. reticularioides. Other major compounds included $\alpha$-bisabolol $(23.63 \%)$ in B. punctulata, spathulenol $(24.74 \%)$ and kongol $(22.22 \%)$ in B. microdonta, $\beta$-pinene $(18.33 \%)$ and limonene $(18.77 \%)$ in B. pauciflosculosa, and $\beta$-pinene $(15.24 \%)$, limonene $(14.33 \%)$, and spathulenol $(13.15 \%)$ in B. sphenophylla. In vitro analyses for antimalarial, antitrypanosomal, and insecticidal activities were conducted for all of the species. B. microdonta and $B$. reticularioides showed good antitrypanosomal activities; $B$. sphenophylla showed insecticidal activities in fumigation bioassay against bed bugs; and B. pauciflosculosa, B. reticularioides, and B. sphenophylla exhibited moderate antimalarial activities. B. microdonta and B. punctulata showed cytotoxicity. The leaves and stems of all five species showed glandular trichomes and ducts as secretory structures. DNA barcoding successfully determined the main DNA sequences of the investigated species and enabled authenticating them.
\end{abstract}

Keywords: Baccharis; antimalarial activity; antitrypanosomal activity; insecticidal activity; GC/MS; DNA barcoding; microscopy

\section{Introduction}

Baccharis L. (Asteraceae) is an important genus comprising 435 species distributed from Argentina to the United States (USA). In Brazil, the genus is represented by 179 species [1]. Several species of Baccharis are frequently used in traditional medicine as analgesic, antidiabetic, anti-inflammatory, digestive, diuretic, and spasmolytic agents [2,3]. These properties provide an excellent rationale for systematically studying their therapeutic properties. However, the correct identification of different 
Baccharis species is challenging due to their morphological similarities. Moreover, many different species of Baccharis are collectively called "vassouras" in Brazil, causing further confusion [4].

Baccharis species have also provided valuable biomolecules in the discovery of new medicinal natural products [5]. Species of the genus produce essential oils (EOs) that are composed mainly of monoterpenoids and sesquiterpenoids. Several such EOs are used in the fragrance industry and for pharmaceutical purposes [3,6-8].

Many of the medicinal properties described for Baccharis are attributed to their EOs [3]. The EOs of the genus have been reported to have several biological activities, including antibacterial, antifungal $[9,10]$, antiprotozoal, antiviral, antioxidant, anti-inflammatory, antimutagenic, antiulcer, chemopreventive, repellent, sedative [7,11-13], schistosomicidal [14], and larvicidal against Aedes aegypti [15] and cytotoxic properties [16]. B. microdonta DC. has shown antibacterial activity against Salmonella typhi [17] and anti-inflammatory properties [18]. Another species, B. pauciflosculosa DC., has exhibited antimicrobial activities [17,19].

However, few studies have been carried out on the chemical analysis of the EOs of Baccharis species [20]. Thus, the major aims of this study were to identify the marker compounds and compare the chemical profiles of the EOs of five Baccharis species, namely B. microdonta, B. pauciflosculosa, B. punctulata DC., B. reticularioides Deble and A.S.Oliveira, and B. sphenophylla Dusén ex Malme, collected from Brazil. To the best of our knowledge, no previous reports exist on the antitrypanosomal, antimalarial, or insecticidal activities of these five species. The study also analyzes the micromorphology of secretory structures, in which the EOs are stored by microscopy and discriminate the species by DNA barcoding.

\section{Results and Discussion}

\subsection{Yield and Chemical Composition of Essential Oils}

Essential oils are liquid, volatile, clear, and rarely colored substances that are soluble in organic solvents and usually of lesser density than water. EOs extracted by hydrodistillation from the vegetative aerial parts of the Baccharis species presented a strong and characteristic aroma. The EO of B. punctulata was green, whereas it was yellow in B. microdonta and light yellow in the other species. The yield of EO was $0.58 \%(v / w)$ in B. microdonta, $0.93 \%(v / w)$ in B. pauciflosculosa, $0.29 \%(v / w)$ in B. punctulata, $0.59 \%(v / w)$ in B. reticularioides, and $0.53 \%(v / w)$ in B. sphenophylla. As per the literature, the yield of EOs in the Baccharis species ranged between 0.08-2.82\%. B. obovata Hook. and Arn. presented the highest yield [21], whereas the lowest content was achieved for B. lateralis Baker (syn. B. schultzii Baker) [22], which were collected in Argentina and Brazil, respectively.

The yield of EOs can be influenced by the physiological variations inherent in the plant, environmental conditions, phenological factors, genetic characteristics of the cultivars, drying conditions applied to the plant material prior to extraction, the process employed for grinding, the storage conditions, and the EO extraction methods [23-25]. Different yields of EOs extracted from the leaves of B. microdonta collected in São Paulo, Brazil were reported. Sayuri et al. [26] showed yields between $0.06-0.35 \%$, whereas Lago et al. [22] presented yields of $0.08-0.21 \%$ for $B$. microdonta. However, these authors extracted the EOs only from the leaves of $B$. microdonta. In the present work, mixtures of leaves and stems were used for extraction. The anatomical study of Baccharis species revealed several large secretory cavities in the cortex of the stems, which may have contributed to the increased yield, as observed by Saulle et al. [27] for Eucalyptus saligna Sm. (Myrtaceae).

Chemically, EOs are complex mixtures that can contain 20-60 compounds in different concentrations, and are characterized by two or three main components with higher concentrations compared to others present in lower concentrations. In general, the major compounds that are present in EOs are responsible for the biological activities $[28,29]$.

The chemical compositions of EOs from the five species of Baccharis were investigated, and their profiles (Figure 1) were compared. Table 1 compares relative retention indices (RRIs) using non-polar 
and polar columns, the literature-reported retention indices (RI lit), chemical identity, and relative peak area percentage (\%) concentration of the chemical constituents of the five species.

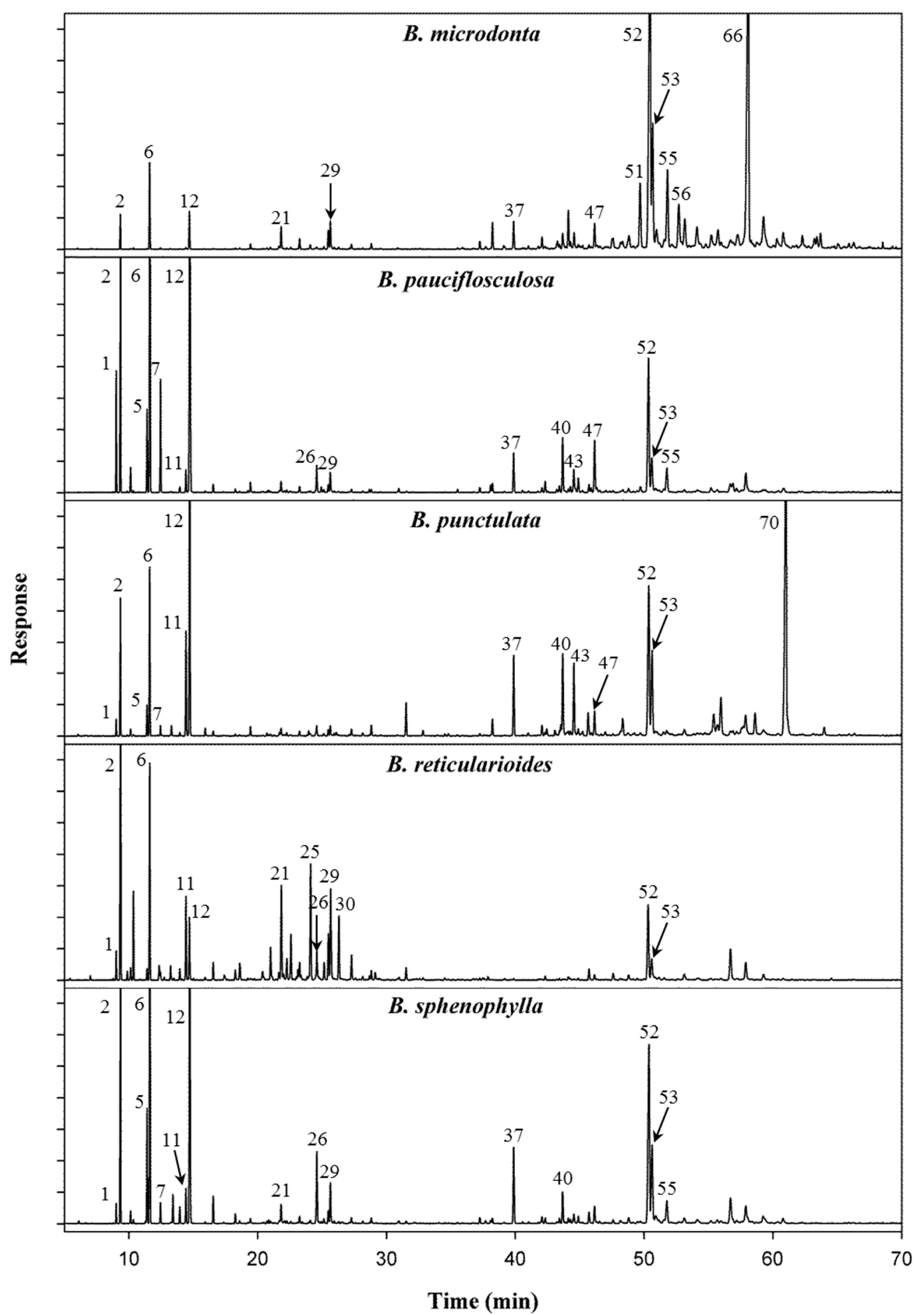

Figure 1. GC chromatograms of Baccharis species obtained for non-polar column. Compound identification is consistent with Table 1.

Monoterpenoids and sesquiterpenoids are frequently found in the EOs of Baccharis [3,30]. Sesquiterpenoids seemed to be more abundant in the majority of the species $[3,6,7,16,22,30-33]$. However, the EO of some species contained more monoterpenoids than sesquiterpenoids, such 
as in B. obovata [21], B. schultzii, B. regnelli Sch. Bip. ex Baker, B. uncinella DC. [22], B. darwinii Hook. \& Arn. [34], B. tridentata Vahl. [33] and B. trimera (Less.) DC. [35]

Considering that raw percentages of volatile compounds are usually reported by the use of the non-polar GC column, in the present work, only these percentages were discussed. Both monoterpenoids and sesquiterpenoids were found in the EOs of all of the Baccharis species that were analyzed, although in different concentrations. Higher concentrations of monoterpenoids $(60.78 \%)$ were found in B. reticularioides, which was formed by $27.45 \%$ of monoterpenoids hydrocarbons and $33.33 \%$ of oxygenated monoterpenoids. In the case of sesquiterpenoids, $B$. microdonta showed the highest concentrations (41.66\%), comprising $18.33 \%$ of sesquiterpenoids hydrocarbons and $23.33 \%$ of oxygenated sesquiterpenoids. The sesquiterpenoid cyclic alcohols found in the present study, such as ledol, spathulenol, viridiflorol, and palustrol, are not only important in the perfume industry due to their agreeable aromatic notes, but also have taxonomic value [33].

A recent bibliographic review reported around 60 compounds identified in the EOs of 16 species of Baccharis that showed biological activities. The main components that were found in these species were $\alpha$-thujene, $\beta$-caryophyllene, $\beta$-pinene, camphor, caryophyllene, caryophyllene oxide, limonene, nerolidol, thymol, thymol acetate, thymol methyl ether, sabinene, and spathulenol [3]. In the present study, $\alpha$-pinene, $\beta$-pinene, limonene, trans-pinocarveol, pinocarvone, myrtenal, $\alpha$-terpineol, cis-carveol, carvone, $\beta$-selinene, $\delta$-cadinene, spathulenol, caryophyllene oxide, and $\delta$-cadinol were found in all of the species of Baccharis studied. However, significant differences in their concentrations were observed.

The compounds' identification is given in Table 1. B. microdonta contained spathulenol (22.74\%) (Figure S2) and kongol (22.22\%) (Figure S1), B. pauciflosculosa showed $\beta$-pinene (18.33\%) and limonene (18.77\%), B. punctulata contained $\alpha$-bisabolol (23.63\%), B. reticularioides presented $\alpha$-pinene $(24.50 \%)$, and B. sphenophylla showed $\alpha$-pinene (10.74\%), $\beta$-pinene $(15.24 \%)$, limonene $(14.33 \%)$, and spathulenol $(13.15 \%)$ as the major compounds. It is important to highlight that kongol and $\alpha$-bisabolol were found only in B. microdonta and B. punctulata, respectively. These compounds can be considered chemical markers for these species.

Differences in the EO chemical compositions have been reported for B. punctulata collected from different geographical locations. The EOs of the samples collected from Uruguay have shown $\beta$-phellandrene (5.2\%), bornyl acetate $(5.2 \%), \alpha$-cadinol $(4.2 \%), \delta$-elemene $(3.7 \%)$, and the ketone shyobunone (3.5\%) as the major compounds [36], whereas the EOs sourced in Guaíba, Brazil have comprised bicyclogermacrene (9.73\%), cis-cadin-4-en-7-ol (6.77\%), and (Z)-ocimene (6.33\%) [23]. Of these compounds, only bornyl acetate (1.32\%) and bicyclogermacrene $(3.10 \%)$ were found in the present study in B. punctulata and in low concentrations. $\alpha$-Bisabolol was not reported in the previous studies, but it was found in higher concentration $(23.63 \%)$ in the present work.

For B. microdonta, Lago et al. [22] reported $24 \%$ of caryophyllene oxide, whereas Sayuri et al. recorded $31 \%$ of elemol, $34 \%$ of spathulenol, $19 \%$ of $\beta$-caryophyllene, and $24 \%$ of germacrene $D$ as the major compounds. Both of these studies used samples collected from Campos do Jordão, Brazil. None of the earlier studies have reported kongol from any of the five Baccharis species, whereas this compound was found in high quantity $(22.22 \%)$ in B. microdonta in the present study. Even though the chemical composition of EOs is frequently associated to environmental and phenological influences, it is necessary to investigate whether these variations in B. punctulata and B. microdonta are possibly linked to different chemotypes. Not only the compositions of EOs, but also the quantities of the compounds vary throughout the life of the plant. This is related to the circadian rhythms, seasonal conditions, and environmental influences that impact the development of the species [24]. To avoid some of these factors, in the present work, all five species were grown in the same locality and collected on the same day and at the same time. Additionally, the sample preparation, hydrodistillation, and characterization of the EOs by GC/MS analysis of all of the materials were performed under the same experimental conditions. 
Table 1. Chemical compositions of the essential oils of Baccharis species. RRI: relative retention indices.

\begin{tabular}{|c|c|c|c|c|c|c|c|c|c|c|c|c|c|c|c|c|}
\hline \multirow{3}{*}{ No. } & \multirow{3}{*}{$\mathrm{RRI}^{\mathrm{a}}$} & \multirow{3}{*}{ RI Lit ${ }^{b}$} & \multirow{3}{*}{ RRI $^{\mathrm{c}}$} & \multirow{3}{*}{ RI Lit ${ }^{d}$} & \multirow{3}{*}{ Compound Name } & \multicolumn{11}{|c|}{ Peak Area $\%^{\mathrm{e}}$} \\
\hline & & & & & & \multicolumn{2}{|c|}{ B. microdonta } & \multicolumn{2}{|c|}{ B. pauciflosculosa } & \multicolumn{2}{|c|}{ B. punctulata } & \multicolumn{2}{|c|}{ B. reticularioides } & \multicolumn{2}{|c|}{ B. sphenophylla } & \multirow{2}{*}{ ID } \\
\hline & & & & & & NC & PC & NC & PC & NC & PC & NC & PC & NC & PC & \\
\hline 1 & 937 & 924 & 1019 & 1038 & $\alpha$-Thujene & - & - & 3.42 & 2.94 & 0.41 & 0.43 & 0.89 & 1.18 & 0.54 & 0.37 & MS, RI \\
\hline 2 & 942 & 932 & 1014 & 1036 & $\alpha$-Pinene & 0.72 & 0.73 & 10.45 & 9.44 & 3.55 & 3.15 & 24.50 & 24.78 & 10.74 & 8.04 & $\mathrm{t}_{R}, \mathrm{MS}, \mathrm{RI}$ \\
\hline 3 & 954 & 946 & 1050 & 1083 & Camphene ${ }^{\mathrm{f}}$ & - & - & 0.78 & 0.75 & 0.19 & 0.18 & 0.43 & 0.42 & 0.39 & 0.30 & $\mathrm{t}_{R}, \mathrm{MS}, \mathrm{RI}$ \\
\hline 4 & 950 & 953 & 1109 & - & Thuja-2,4(10)-diene & - & - & - & - & - & - & 2.91 & 3.65 & 0.12 & 0.09 & MS, RI \\
\hline 5 & 973 & 969 & 1105 & 1130 & Sabinene $\mathrm{f}^{\mathrm{f}}$ & - & - & 2.75 & 2.62 & 0.89 & 0.79 & 0.39 & 0.85 & 3.82 & 3.18 & $\mathrm{t}_{R}, \mathrm{MS}, \mathrm{RI}$ \\
\hline 6 & 976 & 974 & 1089 & 1124 & $\beta$-Pinene & 2.24 & 2.33 & 18.33 & 16.50 & 4.95 & 4.41 & 7.68 & 9.24 & 15.24 & 13.17 & $\mathrm{t}_{R}, \mathrm{MS}, \mathrm{RI}$ \\
\hline 7 & 988 & 988 & 1156 & 1156 & $\beta$-Myrcene & - & - & 3.65 & 2.76 & 0.30 & 0.23 & 0.27 & 0.29 & 0.67 & 0.57 & $\mathrm{t}_{R}, \mathrm{MS}, \mathrm{RI}$ \\
\hline 8 & 1001 & 1002 & 1151 & 1177 & $\alpha$-Phellandrene & - & - & - & - & 0.33 & 0.11 & - & - & - & - & $\mathrm{t}_{R}, \mathrm{MS}, \mathrm{RI}$ \\
\hline 9 & 1003 & 1008 & - & 1141 & $\delta$-(3)-Carene & - & - & - & - & - & - & - & - & 0.99 & 0.82 & $\mathrm{t}_{R}, \mathrm{MS}, \mathrm{RI}$ \\
\hline 10 & 1010 & 1014 & 1198 & 1188 & $\alpha$-Terpinene & - & - & 0.19 & - & 0.10 & - & 0.43 & 0.39 & 0.58 & 0.64 & $\mathrm{t}_{R}, \mathrm{MS}, \mathrm{RI}$ \\
\hline 11 & 1018 & 1020 & 1271 & 1272 & $p$-Cymene & - & - & 0.82 & 1.24 & 3.44 & 1.94 & 3.18 & 3.27 & 1.31 & 1.79 & $\mathrm{t}_{R}, \mathrm{MS}, \mathrm{RI}$ \\
\hline 12 & 1021 & 1024 & 1189 & 1206 & Limonene $\mathrm{f}^{\mathrm{f}}$ & 1.12 & 1.14 & 18.77 & 14.99 & 11.35 & 9.77 & 2.47 & 2.75 & 14.33 & 11.81 & $\mathrm{t}_{R}, \mathrm{MS}, \mathrm{RI}$ \\
\hline 13 & 1040 & 1044 & 1254 & 1250 & trans- $\beta$-Ocimene & - & - & - & - & 0.25 & 0.14 & 0.14 & 0.08 & - & - & MS, RI \\
\hline 14 & 1049 & 1054 & 1243 & 1251 & $\gamma$-Terpinene & - & - & 0.31 & - & 0.16 & 0.06 & 0.70 & 0.38 & 1.03 & 0.41 & $\mathrm{t}_{R}, \mathrm{MS}, \mathrm{RI}$ \\
\hline 15 & 1074 & 1086 & 1267 & 1287 & Terpinolene $\mathrm{f}$ & - & - & - & - & - & - & 0.44 & 0.20 & 0.37 & 0.18 & $\mathrm{t}_{R}, \mathrm{MS}, \mathrm{RI}$ \\
\hline 16 & 1079 & 1089 & 1462 & - & $p$-Cymenene & - & - & - & - & - & - & 0.85 & 1.01 & 0.11 & 0.12 & MS, RI \\
\hline 17 & 1092 & 1095 & 1593 & 1506 & Linalool $^{\mathrm{f}}$ & 0.14 & - & 0.41 & 0.57 & 0.31 & 0.37 & - & - & 0.15 & 0.22 & $\mathrm{t}_{R}, \mathrm{MS}, \mathrm{RI}$ \\
\hline 18 & 1106 & 1101 & 1449 & - & Thujone ${ }^{f}$ & - & - & - & - & - & - & 0.52 & 0.55 & - & - & $\mathrm{t}_{R}, \mathrm{MS}, \mathrm{RI}$ \\
\hline 19 & 1115 & 1122 & 1518 & - & $\alpha$-Campholenal & - & - & - & - & - & - & 1.63 & 2.38 & - & - & MS, RI \\
\hline 20 & 1124 & 1135 & 1607 & - & Nopinone & - & - & - & - & - & - & 0.38 & 0.42 & - & - & MS, RI \\
\hline 21 & 1127 & 1135 & 1695 & - & trans-Pinocarveol & 0.73 & 1.23 & 0.41 & 0.92 & 0.27 & 0.37 & 4.44 & 6.84 & 0.79 & 1.23 & $\mathrm{t}_{R}, \mathrm{MS}, \mathrm{RI}$ \\
\hline 22 & 1133 & 1140 & 1700 & - & $\begin{array}{l}\text { trans-Verbenol } \\
\text { Unknown } 1\end{array}$ & - & - & 0.10 & 0.34 & 0.11 & 0.18 & 0.94 & 0.61 & 0.11 & - & MS, RI \\
\hline 23 & 1138 & - & 1706 & - & $\begin{array}{c}{[\mathrm{m} / \mathrm{z} 94(100 \%), 79} \\
(89.9 \%), 59(79.7 \%), 91 \\
(51.7 \%)]\end{array}$ & - & - & - & - & - & - & 2.12 & 2.10 & - & - & MS \\
\hline 24 & 1148 & 1160 & 1597 & - & Pinocarvone $\mathrm{f}$ & 0.32 & 0.29 & 0.26 & 0.16 & 0.16 & 0.09 & 0.80 & 1.03 & 0.27 & 0.34 & $\mathrm{t}_{R}, \mathrm{MS}, \mathrm{RI}$ \\
\hline 25 & 1161 & - & 1769 & - & $\alpha$-Phellandren-8-ol & - & - & - & - & - & - & 5.60 & 3.72 & 0.15 & 0.03 & MS \\
\hline 26 & 1168 & 1174 & 1643 & 1628 & Terpinene-4-ol ${ }^{\mathrm{f}}$ & - & - & 1.19 & 1.23 & 0.47 & 0.44 & 1.34 & 1.29 & 3.10 & 3.45 & $\mathrm{t}_{R}, \mathrm{MS}, \mathrm{RI}$ \\
\hline 27 & 1176 & 1179 & 1882 & 1846 & p-Cymene-8-ol & - & - & 0.11 & 0.17 & - & - & 0.83 & 1.16 & 0.21 & 0.32 & MS, RI \\
\hline 28 & 1181 & 1195 & 1659 & - & Myrtenal $^{\mathrm{f}}$ & 0.59 & 0.67 & 0.34 & 0.41 & 0.24 & 0.27 & 2.14 & 3.25 & 0.53 & 0.62 & $\mathrm{t}_{R}, \mathrm{MS}, \mathrm{RI}$ \\
\hline 29 & 1184 & 1186 & 1740 & 1731 & $\alpha$-Terpineol & 0.97 & 0.65 & 0.92 & 0.74 & 0.42 & 0.26 & 4.82 & 0.61 & 1.85 & 1.42 & $\mathrm{t}_{R}, \mathrm{MS}, \mathrm{RI}$ \\
\hline 30 & 1193 & 1204 & 1737 & 1733 & Verbenone $\mathrm{f}$ & - & - & - & - & - & - & 2.95 & 2.65 & - & - & $\mathrm{t}_{R}, \mathrm{MS}, \mathrm{RI}$ \\
\hline
\end{tabular}


Table 1. Cont

\begin{tabular}{|c|c|c|c|c|c|c|c|c|c|c|c|c|c|c|c|c|}
\hline \multirow{3}{*}{ No. } & \multirow{3}{*}{$\mathrm{RRI}^{\mathrm{a}}$} & \multirow{3}{*}{ RI Lit ${ }^{b}$} & \multirow{3}{*}{ RRI $^{c}$} & \multirow{3}{*}{ RI Lit ${ }^{d}$} & \multirow{3}{*}{ Compound Name } & \multicolumn{11}{|c|}{ Peak Area \% ${ }^{\text {e }}$} \\
\hline & & & & & & \multicolumn{2}{|c|}{ B. microdonta } & \multicolumn{2}{|c|}{ B. pauciflosculosa } & \multicolumn{2}{|c|}{ B. punctulata } & \multicolumn{2}{|c|}{ B. reticularioides } & \multicolumn{2}{|c|}{ B. sphenophylla } & \multirow{2}{*}{ ID } \\
\hline & & & & & & $\mathrm{NC}$ & PC & $\mathrm{NC}$ & PC & $\mathrm{NC}$ & PC & NC & PC & NC & PC & \\
\hline 31 & 1208 & 1225 & 1850 & 1820 & cis-Carveol & 0.15 & - & 0.13 & 0.34 & 0.27 & 0.30 & 1.19 & 1.15 & 0.27 & 0.38 & MS, RI \\
\hline 32 & 1231 & 1239 & 1765 & 1715 & Carvone $^{\mathrm{f}}$ & 0.17 & - & 0.13 & 0.22 & 0.42 & 0.46 & 0.43 & 0.46 & 0.22 & 0.31 & MS, RI \\
\hline 33 & 1235 & - & 1867 & - & 2-Carene-4-ol & - & - & - & - & - & - & 0.32 & 0.17 & - & - & MS \\
\hline 34 & 1271 & 1284 & 1615 & 1599 & Bornyl acetate $\mathrm{f}^{\mathrm{f}}$ & - & - & - & - & 1.32 & 1.04 & 0.60 & 0.51 & 0.12 & 0.09 & $\mathrm{t}_{R}, \mathrm{MS}, \mathrm{RI}$ \\
\hline 35 & 1356 & 1374 & 1515 & 1493 & $\alpha$-Copaene & 0.26 & 0.28 & 0.21 & 0.33 & - & - & - & - & 0.26 & 0.34 & MS, RI \\
\hline 36 & 1370 & 1389 & 1621 & 1591 & $\beta$-Elemene & 0.87 & 1.10 & 0.41 & 0.51 & 0.67 & 0.53 & - & - & 0.23 & - & MS, RI \\
\hline 37 & 1395 & 1417 & 1624 & 1617 & $\beta$-Caryophyllene & 0.97 & 0.92 & 1.80 & 1.55 & 3.35 & 2.76 & - & - & 3.61 & 3.46 & $\mathrm{t}_{R}, \mathrm{MS}, \mathrm{RI}$ \\
\hline 38 & 1427 & 1437 & 1707 & 1672 & $\alpha$-Humulene & 0.39 & 0.26 & 0.19 & - & 0.42 & 0.41 & - & - & 0.31 & 0.12 & $\mathrm{t}_{R}, \mathrm{MS}, \mathrm{RI}$ \\
\hline 39 & 1447 & 1478 & 1720 & 1692 & $\gamma$-Muurolene & 0.15 & 0.28 & 0.26 & 0.56 & 0.17 & 0.54 & - & - & 0.27 & 0.47 & MS, RI \\
\hline 40 & 1451 & 1484 & 1737 & 1712 & Germacrene-D & 0.64 & 0.41 & 2.56 & 0.68 & 3.63 & 2.48 & - & - & 1.44 & 0.80 & MS, RI \\
\hline 41 & 1458 & 1489 & 1746 & 1756 & $\beta$-Selinene & 1.35 & 1.23 & 0.15 & 0.11 & 0.12 & 0.16 & 0.18 & 0.07 & 0.24 & 0.21 & MS, RI \\
\hline 42 & 1460 & 1496 & 1725 & - & Ledene $^{f}$ & - & - & 0.29 & 0.10 & 0.12 & 0.13 & - & - & 0.17 & 0.14 & $\mathrm{t}_{R}, \mathrm{MS}, \mathrm{RI}$ \\
\hline 43 & 1464 & 1500 & 1761 & 1744 & Bicyclogermacrene $\mathrm{f}^{\mathrm{f}}$ & - & - & 1.25 & 0.01 & 3.10 & 2.85 & - & - & 0.48 & 0.05 & MS, RI \\
\hline 44 & 1464 & 1498 & 1751 & 1729 & $\alpha$-Selinene & 0.58 & 0.48 & - & - & - & & - & & - & & MS, RI \\
\hline 45 & 1469 & 1500 & 1756 & 1730 & $\alpha$-Muurolene & 0.14 & - & 0.63 & 0.73 & 0.26 & 0.27 & - & - & 0.29 & 0.26 & MS, RI \\
\hline 46 & 1480 & 1505 & 1705 & 1745 & $\beta$-Bisabolene & - & - & - & - & 1.18 & 0.78 & - & - & - & - & MS, RI \\
\hline 47 & 1488 & 1522 & 1787 & 1761 & $\delta$-Cadinene & 1.00 & 1.17 & 2.74 & 1.96 & 1.13 & 1.35 & 0.28 & 1.04 & 0.79 & 1.52 & MS, RI \\
\hline 48 & 1509 & 1544 & 1930 & 1916 & $\alpha$-Calacorene & 0.78 & 0.37 & - & - & - & - & 0.43 & 0.18 & 0.18 & 0.21 & MS, RI \\
\hline 49 & 1520 & 1548 & 2080 & 2078 & Elemol $^{\mathrm{f}}$ & - & - & 0.12 & - & 1.02 & 1.09 & - & - & - & - & MS, RI \\
\hline 50 & 1537 & 1561 & 2051 & 2044 & (E)-Nerolidol & - & - & 0.43 & 0.60 & 0.13 & 0.30 & - & - & 0.17 & 0.17 & MS, RI \\
\hline 51 & 1540 & 1567 & 1942 & 1931 & Palustrol ${ }^{\mathrm{f}}$ & 3.23 & 3.22 & - & - & 0.13 & - & - & - & - & - & MS, RI \\
\hline 52 & 1551 & 1577 & 2114 & 2153 & Spathulenol $\mathrm{f}$ & 22.74 & 24.19 & 9.53 & 12.18 & 9.96 & 11.66 & 5.52 & 2.70 & 13.15 & 14.92 & $\mathrm{t}_{R}, \mathrm{MS}, \mathrm{RI}$ \\
\hline 53 & 1555 & 1582 & 1987 & 1966 & Caryophyllene oxide ${ }^{f}$ & 6.84 & 7.47 & 2.11 & 3.44 & 5.30 & 6.01 & 1.37 & 1.34 & 5.34 & 6.78 & $\mathrm{t}_{R}, \mathrm{MS}, \mathrm{RI}$ \\
\hline 54 & 1559 & 1590 & 2128 & - & Globulol & 0.59 & 0.69 & - & - & - & - & - & - & 0.36 & 0.32 & MS, RI \\
\hline 55 & 1571 & 1592 & 2080 & 2112 & Viridiflorol $^{\mathrm{f}}$ & 4.36 & 4.90 & 1.81 & 2.69 & - & - & - & - & 1.66 & 2.01 & $\mathrm{t}_{R}, \mathrm{MS}, \mathrm{RI}$ \\
\hline 56 & 1585 & 1602 & 2031 & - & Ledol $^{\mathrm{f}}$ & 2.38 & 2.55 & - & - & - & - & - & - & - & - & MS, RI \\
\hline 57 & 1622 & 1627 & 2063 & 2037 & 1-epi-Cubenol & 1.03 & 0.57 & 0.38 & 0.39 & - & - & - & - & - & - & MS, RI \\
\hline 58 & 1625 & 1630 & - & - & $\begin{array}{l}\gamma \text {-Eudesmol } \\
\text { Unknown } 2\end{array}$ & - & - & - & - & 1.09 & 1.65 & - & - & - & - & MS, RI \\
\hline 59 & 1630 & - & - & - & $\begin{array}{c}{[\mathrm{m} / \mathrm{z} 119(100 \%), 105} \\
(92.9 \%), 91(90.2 \%), 93 \\
(79.5 \%)]\end{array}$ & 1.37 & 1.22 & - & - & - & - & - & - & - & - & MS \\
\hline 60 & 1633 & 1638 & 2094 & - & epi- $\alpha$-Cadinol & 0.18 & 0.38 & - & - & 1.95 & 2.09 & - & - & - & - & MS, RI \\
\hline 61 & 1644 & 1644 & 2151 & 2150 & $\delta$-Cadinol & 0.42 & 0.33 & 0.77 & 0.65 & 0.26 & 0.64 & 2.64 & 1.56 & 2.27 & 2.03 & MS, RI \\
\hline 62 & 1647 & 1640 & 2164 & - & epi- $\alpha$-Muurolol & 0.19 & - & 0.65 & 0.75 & 0.27 & 0.33 & - & - & - & - & MS, RI \\
\hline 63 & 1659 & 1649 & 2196 & 2248 & $\beta$-Eudesmol & - & - & - & - & 0.64 & 1.65 & - & - & - & - & $\mathrm{t}_{R}, \mathrm{MS}, \mathrm{RI}$ \\
\hline
\end{tabular}


Table 1. Cont.

\begin{tabular}{|c|c|c|c|c|c|c|c|c|c|c|c|c|c|c|c|c|}
\hline \multirow{3}{*}{ No. } & \multirow{3}{*}{$\mathbf{R R I}^{\mathrm{a}}$} & \multirow{3}{*}{ RI Lit ${ }^{b}$} & \multirow{3}{*}{ RRI $^{c}$} & \multirow{3}{*}{ RI Lit ${ }^{d}$} & \multirow{3}{*}{ Compound Name } & \multicolumn{11}{|c|}{ Peak Area $\%{ }^{\mathrm{e}}$} \\
\hline & & & & & & \multicolumn{2}{|c|}{ B. microdonta } & \multicolumn{2}{|c|}{ B. pauciflosculosa } & \multicolumn{2}{|c|}{ B. punctulata } & \multicolumn{2}{|c|}{ B. reticularioides } & \multicolumn{2}{|c|}{ B. sphenophylla } & \multirow{2}{*}{ ID } \\
\hline & & & & & & $\mathrm{NC}$ & PC & NC & PC & $\mathrm{NC}$ & PC & NC & PC & NC & PC & \\
\hline 64 & 1661 & 1656 & 2120 & - & $\alpha$-Bisabolol oxide B & - & - & - & - & 1.17 & 0.47 & - & - & - & - & MS, RI \\
\hline 65 & 1662 & 1652 & 2200 & 2224 & $\alpha$-Cadinol & - & - & 1.44 & 2.08 & - & - & 1.36 & 0.46 & 1.49 & 2.10 & MS, RI \\
\hline 66 & 1665 & - & 2214 & - & Kongol & 22.22 & 20.09 & - & - & - & - & - & - & - & - & $\mathrm{t}_{R}, \mathrm{MS}$ \\
\hline 67 & 1672 & 1675 & 2209 & 2203 & Cadalene & - & - & - & - & 1.34 & 1.32 & - & - & - & - & MS, RI \\
\hline 68 & 1697 & - & 2278 & - & $\begin{array}{c}\text { Murolan-3,9(11)-diene- } \\
10-p e r o x y \\
(1 R, 7 S, E) \text {-7-Isopropyl- }\end{array}$ & 0.54 & 0.64 & - & - & - & - & - & - & - & - & MS \\
\hline 69 & 1705 & - & 2292 & - & $\begin{array}{l}\text { 4,10-dimethylenecyclodec- } \\
\text { 5-enol }\end{array}$ & 0.83 & 0.94 & 0.39 & 0.28 & - & - & - & - & 0.42 & 0.46 & MS \\
\hline \multirow[t]{6}{*}{70} & 1708 & 1685 & 2190 & 2022 & $\alpha$-Bisabolol & - & - & - & - & 23.63 & 20.72 & - & - & - & - & $\mathrm{t}_{R}, \mathrm{MS}, \mathrm{RI}$ \\
\hline & \multicolumn{5}{|c|}{ Compounds identified (\%) } & 58.33 & 52.63 & 77.36 & 67.27 & 77.96 & 73.33 & 74.50 & 66.66 & 76.66 & 69.84 & \\
\hline & \multirow{2}{*}{\multicolumn{5}{|c|}{$\begin{array}{l}\text { Monoterpenoids hydrocarbons } \\
\text { Oxygenated monoterpenoids }\end{array}$}} & 6.67 & 5.26 & 20.75 & 16.36 & 22.03 & 20.00 & 27.45 & 24.56 & 25.00 & 23.81 & \\
\hline & & & & & & 10.00 & 7.02 & 16.98 & 16.36 & 15.26 & 15.00 & 33.33 & 29.82 & 18.33 & 15.87 & \\
\hline & \multirow{2}{*}{\multicolumn{5}{|c|}{$\begin{array}{l}\text { Sesquiterpenoids hydrocarbons } \\
\text { Oxygenated sesquiterpenoids }\end{array}$}} & 18.33 & 17.54 & 20.75 & 18.19 & 18.64 & 18.33 & 5.88 & 5.26 & 20.00 & 17.46 & \\
\hline & & & & & & 23.33 & 22.81 & 18.88 & 16.36 & 22.03 & 20.00 & 7.84 & 7.02 & 13.33 & 12.70 & \\
\hline
\end{tabular}

$\mathrm{RRI}^{\mathrm{a}}$, relative retention indices calculated against n-alkanes on the DB-5MS column; RI lit ${ }^{\mathrm{b}}$, retention index literature (DB-5 column) [37]; RRI ${ }^{\mathrm{c}}$, relative retention indices calculated against n-alkanes on the DB-WAX column; RI lit ${ }^{\mathrm{d}}$, retention index literature (CW20M column) [38], Peak Area ${ }^{\mathrm{e}}{ }^{\mathrm{e}}$; stereoisomers not identified ${ }^{\mathrm{f}}$; NC, non-polar column; PC, polar column, $t_{R}$, identification based on the retention times $\left(t_{R}\right)$ of genuine compounds on the DB-5MS column; MS, identified on the basis of computer matching of the mass spectra with those of the Wiley and NIST libraries and comparison with literature data. The compounds in bold represent the major compounds. 
Retta et al. [8] analyzed five species of Baccharis, namely B. gaudichaudiana DC., B. microcephala (Less.) DC., B. penningtonii Heering, B. phyteumoides (Less.) DC., and B. spicata (Lam.) Baill., and reported that they were qualitatively, but not quantitatively, similar. In the present study, although the five species presented similar qualitative patterns, some compounds were found only in one specific species. Qualitative similarities in these species were expected, as they belonged to the same genus. However, they were classified into two different taxonomic groups: B. punctulata belonged to subgenus Molina, whereas the other four species belonged to the subgenus Baccharis.

By comparing the GC chromatograms of the EOs of the five species of Baccharis, it is possible to distinguish them by the quality and quantity of their major constituents (Figure 1).

\subsection{Antimalarial Activity}

In order to explore the antimalarial properties of the five species of Baccharis, their EOs were investigated against chloroquine-sensitive (D6) and chloroquine-resistant (W2) strains of Plasmodium falciparum (Table 2). The EOs of B. microdonta and B. punctulata were cytotoxic to Vero cells (selectivity control), and because of this result, they were not indicated to be used in cellular media as an antimalarial. These two EOs differed from other studied species due to the presence of the chemical markers spathulenol (22.74\%) and kongol (22.22\%) for B. microdonta and $\alpha$-bisabolol for B. punctulata (23.63\%). Due to their cytotoxic properties, these EOs can be further explored in other cytotoxicity or anticancer studies, as previously reported by Pereira et al. for B. milleflora DC. [16]. Otherwise, the EO of B. pauciflosculosa showed moderate antimalarial activity against both P. falciparum clones (lower than $15 \mu \mathrm{g} / \mathrm{mL}$ ), while B. reticularioides and B. sphenophylla demonstrated discrete antimalarial effects. Significant differences in the quality and quantity of the chemical components of the five EOs can be strongly related to these data. In particular, the variation in the quantities of the main components e.g., monoterpenes $\beta$-pinene (18.33\%) and limonene (18.77\%), might be responsible for the antimalarial effect of the EO of B. pauciflosculosa.

Table 2. Activities of essential oils of Baccharis species against Plasmodium falciparum.

\begin{tabular}{|c|c|c|c|c|c|}
\hline \multirow{2}{*}{ Sample Name } & \multicolumn{2}{|c|}{ P. falciparum (D6 Clone) } & \multicolumn{2}{|c|}{ P. falciparum (W2 Clone) } & \multirow{2}{*}{$\begin{array}{l}\text { Cytotoxicity } \\
\text { (Vero Cells) } \\
\text { IC }_{50}(\mu \mathrm{g} / \mathrm{mL})\end{array}$} \\
\hline & $\mathrm{IC}_{50}(\mu \mathrm{g} / \mathrm{mL})$ & SI & $\mathrm{IC}_{50}(\mu \mathrm{g} / \mathrm{mL})$ & SI & \\
\hline B. microdonta & $14.75 \pm 3.80$ & 2.4 & $23.93 \pm 4.64$ & 1.5 & $35.80 \pm 7.29$ \\
\hline B. pauciflosculosa & $10.90 \pm 0.98$ & $>4.3$ & $14.20 \pm 1.08$ & $>3.3$ & NC \\
\hline B. punctulata & $17.26 \pm 0.83$ & 2.2 & $19.73 \pm 4.11$ & 1.9 & $37.81 \pm 6.36$ \\
\hline B. reticularioides & $20.32 \pm 4.37$ & $>2.3$ & $34.35 \pm 10.15$ & $>1.4$ & NC \\
\hline B. sphenophylla & $27.58 \pm 1.64$ & $>1.7$ & $32.53 \pm 16.5$ & $>1.5$ & $\mathrm{NC}$ \\
\hline Chloroquine & 0.014 & $>17$ & 0.117 & $>2$ & NC \\
\hline Artemisinin & 0.004 & $>31.8$ & 0.003 & $>71.3$ & $\mathrm{NC}$ \\
\hline
\end{tabular}

NC: No cytotoxicity up to $47.6 \mu \mathrm{g} / \mathrm{mL}$ of essential oils and $0.238 \mu \mathrm{g} / \mathrm{mL}$ for chloroquine and artemisinin; SI: selectivity index ( $\mathrm{IC}_{50}$ for cytotoxicity $/ \mathrm{IC}_{50}$ for antimalarial activity); values were measured in triplicate $(n=3)$.

They are presented as mean \pm SD.

In the genus Baccharis, antimalarial studies were carried out for a few species using their plant extracts or isolated compounds. B. dracunculifolia DC. is the most important plant source of the Brazilian green propolis, and showed antimalarial activities against $P$. falciparum (D6) using crude hydroalcoholic green propolis extract $(13 \mu \mathrm{g} / \mathrm{mL})$ and hautriwaic acid lactone with $\mathrm{IC}_{50}$ values of $0.8 \mu \mathrm{g} / \mathrm{mL}$ (D6 clone) and $2.2 \mu \mathrm{g} / \mathrm{mL}$ (W2 clone) [39]. The extracts of leaves from B. rufescens Spreng. and B. genistelloides (Lam.) Pers. also showed in vitro antimalarial activity, achieving $100 \%$ of inhibition at $100 \mu \mathrm{g} / \mathrm{mL}$ against a P. falciparum chloroquine-resistant strain [40]. In spite of the antiplasmodial activity of plant EOs widely reported in the literature [28], the present work represents the first study involving the antimalarial effect using the EOs of the Baccharis species.

Additionally, the selectivity index (SI) was calculated to predict how toxic the samples were to normal cells. The calculated selectivity indices showed that B. pauciflosculosa had better selectivity to P. falciparum clones than for Vero cells. This EO was safer than other examined samples, making it a candidate for further development as an antimalarial agent, mainly via the inhalation route. 


\subsection{Antitrypanosomal Activity}

Trypanosoma brucei is a protozoan that causes human African trypanosomiasis (HAT). There are currently only four drugs available for its treatment, namely pentamidine, melarsoprol, suramin, and eflornithine. Considering the lack of phytochemical and pharmacological data available for plants with efficacy against trypanosomes and aiming at proposing alternative treatments for HAT, an initial screening of the EOs of the five species of Baccharis were carried out against T. brucei (Table 3).

All five species presented remarkable antitrypanosomal activities at concentrations ranging from $0.31-1.69 \mu \mathrm{g} / \mathrm{mL}\left(\mathrm{IC}_{50}\right)$ and $0.52-2.68 \mu \mathrm{g} / \mathrm{mL}\left(\mathrm{IC}_{90}\right)$. B. pauciflosculosa demonstrated the highest effect, $0.31 \mu \mathrm{g} / \mathrm{mL}\left(\mathrm{IC}_{50}\right)$ and $0.52 \mu \mathrm{g} / \mathrm{mL}\left(\mathrm{IC}_{90}\right)$, followed by B. reticularioides, which showed $0.96 \mu \mathrm{g} / \mathrm{mL}$ $\left(\mathrm{IC}_{50}\right)$ and $2.49 \mu \mathrm{g} / \mathrm{mL}\left(\mathrm{IC}_{90}\right)$, and B. sphenophylla, which presented $1.14 \mu \mathrm{g} / \mathrm{mL}\left(\mathrm{IC}_{50}\right)$ and $2.38 \mu \mathrm{g} / \mathrm{mL}$ $\left(\mathrm{IC}_{90}\right)$. This is the first report on the antitrypanosomal activities for these species. Good EO activity was also reported for other species, such as Cymbopogon giganteus Chiov. (Poaceae) ( $\mathrm{IC}_{50} \mathrm{of} 0.25 \mu \mathrm{g} / \mathrm{mL}$ ) [41] and Juniperus oxycedrus L. (Cupressaceae) $\left(\mathrm{IC}_{50}\right.$ of $0.9 \mu \mathrm{g} / \mathrm{mL}$ ) [42].

Costa et al. [42] investigated some isolated monoterpenoids (1,8-cineole, borneol, camphor, carvacrol, citral, eugenol, linalool, thymol, and $\alpha$-pinene) against T. brucei. $\alpha$-Pinene and citral exhibited the highest activities with $\mathrm{IC}_{50}$ values of $2.9 \mu \mathrm{g} / \mathrm{mL}$ and $18.9 \mu \mathrm{g} / \mathrm{mL}$, respectively. Therefore, the activities observed in this work could be attributed to the presence of $\alpha$-pinene in the EOs of B. pauciflosculosa $(10.45 \%)$, B. reticularioides $(24.50 \%)$, and B. sphenophylla $(10.74 \%)$. B. microdonta and B. punctulata demonstrated a lower antitrypanosomal effect than other species, and contained low concentrations of $\alpha$-pinene $(0.72 \%$ and $3.55 \%$, respectively).

Table 3. In vitro antitrypanosomal activity of essential oils of Baccharis species against T. brucei.

\begin{tabular}{|c|c|c|}
\hline Sample Name & $\mathrm{IC}_{50}(\mu \mathrm{g} / \mathrm{mL}) *$ & $\mathrm{IC}_{90}(\mu \mathrm{g} / \mathrm{mL}) *$ \\
\hline B. microdonta & $1.688 \pm 0.354$ & $2.683 \pm 0.123$ \\
\hline B. pauciflosculosa & $0.306 \pm 0.056$ & $0.516 \pm 0.043$ \\
\hline B. punctulata & $1.054 \pm 0.211$ & $1.969 \pm 0.201$ \\
\hline B. reticularioides & $0.955 \pm 0.121$ & $2.484 \pm 0.165$ \\
\hline B. sphenophylla & $1.143 \pm 0.113$ & $2.378 \pm 0.201$ \\
\hline Pentamidine & $0.007 \pm 0.001$ & $0.011 \pm 0.002$ \\
\hline$\alpha$-Difluoromethylornithine (DFMO) & $5.506 \pm 0.412$ & $12.052 \pm 0.613$ \\
\hline
\end{tabular}

\subsection{Insecticidal Studies with Bed Bugs}

Most of the plant-based insecticides and repellents are derived from plants containing EOs [43]. In addition, receptors responding to DEET ( $N, N$-diethyl-3-methylbenzamide) can also respond to volatile terpenes [44]. Therefore, this exploratory study was aimed at investigating the insecticidal potential of EOs of Baccharis species against bed bugs because of the increasing demands for information about effective control tactics and their public health risks.

The results of fumigation studies involving bed bugs are illustrated in Figure 2. Out of the five EOs analyzed, only B. sphenophylla produced $66.67 \pm 3.33 \%$ mortality in the insecticide-resistant strain 'Bayonne', while producing $83.33 \pm 3.33 \%$ mortality in the susceptible strain 'Ft.Dix', $24 \mathrm{~h}$ after treatment. All of the other EOs showed less than $15 \%$ mortality. In particular, B. sphenophylla EO exhibited a wide range of volatile compounds with no specific chemical markers. In that sense, its fumigation effect could be attributed to the synergic effects of terpenes, as previously reported in the literature [45]. Several monoterpenes were isolated and demonstrated fumigation effects on different insects, e.g., $\alpha$-pinene, $\beta$-pinene, 3 -carene, limonene, myrcene, $\alpha$-terpinene, and camphene [43]. Of these compounds described in the literature, only camphene was not present in the EO of B. sphenophylla, which reinforces the hypothesis that its effect was based on a synergism of various volatile compounds present in the EO. 


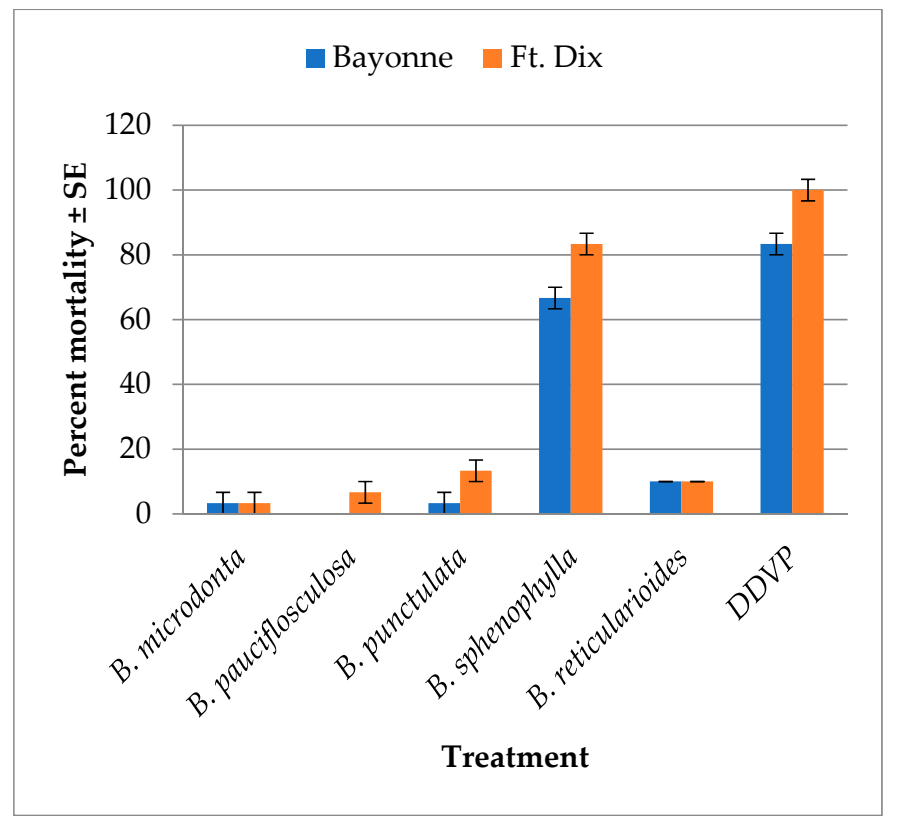

Figure 2. Mean percent mortality $( \pm \mathrm{SE})$ caused by the essential oils of five species of Baccharis against two strains of bed bugs (Cimex lectularius) $24 \mathrm{~h}$ after treatment in a fumigation bioassay. Essential oil dose: $250 \mu \mathrm{g} / 125 \mathrm{~mL}$ of air, 2,2-dichlorovinyl dimethyl phosphate (DDVP) used as standard $(2 \mu \mathrm{g} / 125 \mathrm{~mL}$ of air). Mean and standard error were calculated in John's Macintosh Project (JMP) 10.0.

None of the EOs showed high mortality when applied topically at $50 \mu \mathrm{g} / \mathrm{bug}$. Only in B. punctulata did the mortality reach $20 \%$ seven days after the treatment (Figure 3). In residual study, none of the EOs produced mortality in bed bugs seven days of exposure at $100 \mu \mathrm{g} / \mathrm{cm}^{2}$.

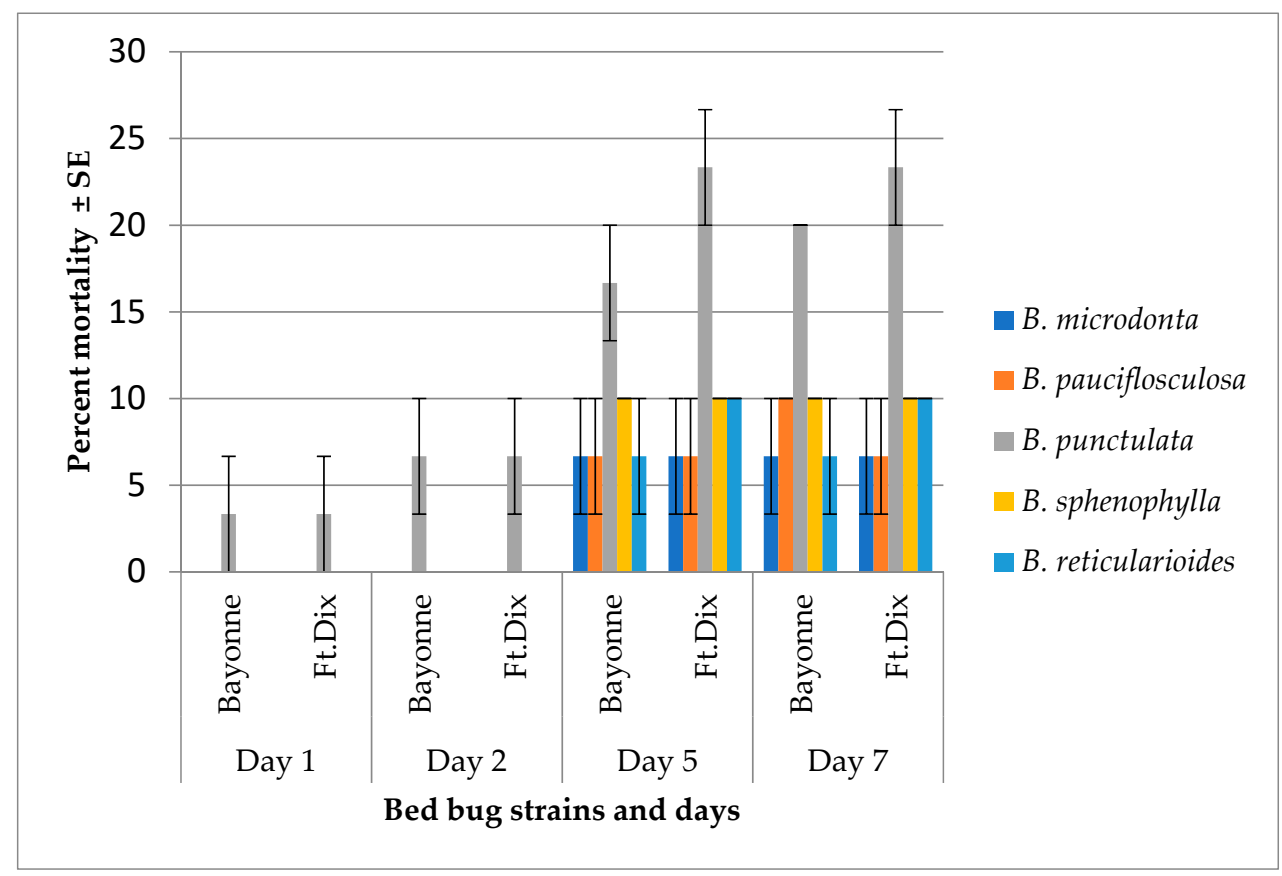

Figure 3. Mean percent mortality $( \pm \mathrm{SE})$ caused by the essential oils (EOs) of five species of Baccharis applied topically on bed bug Cimex lectularius. Essential oil dose: $50 \mu \mathrm{g} / \mathrm{bug}$, deltamethrin (standard) produced $100 \%$ (Ft. Dx.) and 56.67\% (Bayonne) mortality at $2.4 \mathrm{ng} / \mathrm{bug} 24 \mathrm{~h}$ after treatment. Mean and standard error were calculated in JMP 10.0. 


\subsection{Secretory Structures}

In Asteraceae, EOs are biosynthesized and accumulated in various secretory structures, such as idioblast oil cells, oil cavities, secretory ducts, and glandular trichomes [46]. In Baccharis, EOs can be found in roots, stems, leaves and flowers $[35,47,48]$, and are stored in secretory ducts and glandular trichomes [4].

In the present study, the leaves and stems of all of the Baccharis species showed glandular trichomes, either isolated or in clusters (Figure $4 \mathrm{a}-\mathrm{d}$ ), and frequently inserted in small epidermal depressions. There were three types of glandular trichomes, namely biseriate (Figure 4a,c,d), flagelliform with straight body (Figure 4a,b,d), and flagelliform C-shaped (Figure 4c). Biseriate glandular trichomes were present in all of the species, except for B. pauciflosculosa. The flagelliform trichomes with straight body were found in all of the species except B. punctulata, and only this species had flagelliform C-shaped trichomes (Figure 4c).
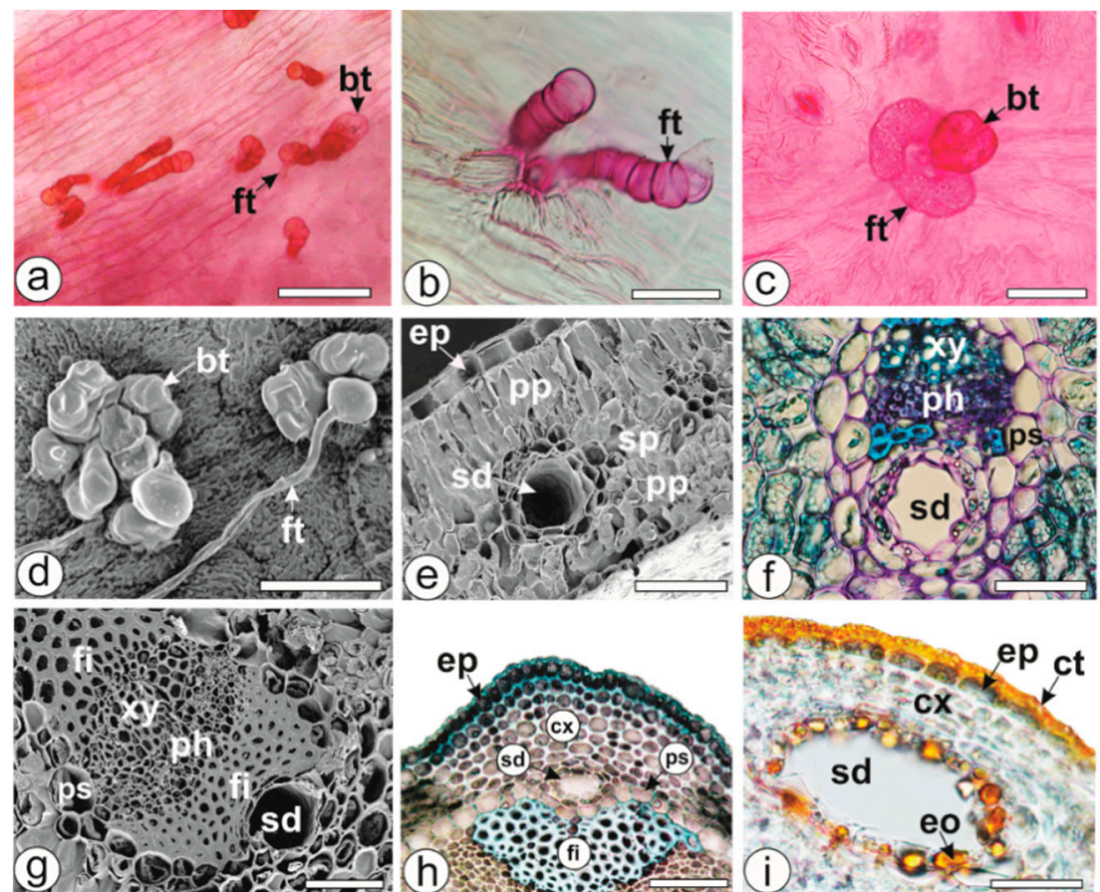

Figure 4. Anatomy of Baccharis [light $(\mathbf{a}, \mathbf{b}, \mathbf{c}, \mathbf{f}, \mathbf{h}, \mathbf{i})$ and scanning electron microscopy $(\mathbf{d}, \mathbf{e}, \mathbf{g})]$. Leaf epidermis in surface view (a-d), cross-sections of the leaf $(\mathbf{e}-\mathbf{g})$ and of the stem $(\mathbf{h}, \mathbf{i})$. B. microdonta $(\mathbf{a})$, B. pauciflosculosa $(\mathbf{b}, \mathbf{e}, \mathbf{f})$, B. punctulata $(\mathbf{c}, \mathbf{h})$, B. reticularioides $(\mathbf{d}, \mathbf{g})$, B. sphenophylla (i). [bt-biseriate glandular trichome, ct—cuticle, cx-cortex, eo-essential oil, ep-epidermis, fi-fibers, ft-flagelliform trichome, ph-phloem, pp-palisade parenchyma, sd-secretory ducts, sp-spongy parenchyma, xy—xylem]. Scale bars: $\mathbf{b}, \mathbf{c}, \mathbf{d}, \mathbf{f}, \mathbf{g}, i=50 \mu \mathrm{m} ; e=100 \mu \mathrm{m} ; \mathbf{a}, h=200 \mu \mathrm{m}$.

All the studied Baccharis species presented secretory ducts in the mesophyll (Figure 4e,f) and midrib of the leaves (Figure $4 \mathrm{~g}$ ), and in the cortex of the stems (Figure $4 \mathrm{~h}, \mathrm{i}$ ). They showed a uniseriate epithelium formed by four to 20 cells with large nuclei and dense cytoplasm containing EO droplets, and were found next to the parenchyma sheath near the phloem (Figure $4 \mathrm{e}-\mathrm{i}$ ). These secretory ducts could also sometimes release other chemical compounds such as resins and tannins beside EOs [49]. Essential oils in the trichomes and ducts, and lipophilic compounds in the cuticle reacted positively with Sudan III in the histochemical tests (Figure 4i).

\subsection{Identification of the Samples by DNA}

Classical methods for the identification of medicinal plants include organoleptic, macroscopic, and microscopic methods and chemical profiling. Modern techniques, such as DNA barcoding, have 
emerged recently and are often used in plant identification [50]. Considering the morphological similarities among Baccharis species [4], all four genomic regions, namely ITS, ETS, psbA-trnH, and trnL-trnF were subjected to amplification and sequencing in order to provide molecular data for the differentiation of the species. Only two samples (ECT0000641, ECT0000642) resulted in an ETS PCR product and consequently sequence data. Only a single sequence per authenticated species was available for sequence comparison. Table 4 shows KP2 distances between five Baccharis samples and authenticated species. The KP2 value determines the genetic distance between samples and the lowest KP2 value of 0.000 indicates a $100 \%$ match. The psbA-trnH sequences of samples $B$. reticularioides (ECT0000642) and B. sphenophylla (ECT0000647) matched 100\% to three different species, indicating that the genomic region has not much variation in its sequence to be helpful to distinguish between species.

Table 4. KP2 distances between five Baccharis samples and authenticated species.

\begin{tabular}{|c|c|c|c|c|c|c|c|c|c|c|c|}
\hline \multirow[b]{2}{*}{ Sample } & \multicolumn{2}{|c|}{$\begin{array}{c}\text { Lowest Kp } \\
\text { Distance (ITS) }\end{array}$} & \multicolumn{2}{|c|}{$\begin{array}{c}\text { Lowest Kp } \\
\text { Distance (trnL-trnF) }\end{array}$} & \multicolumn{2}{|c|}{$\begin{array}{c}\text { Lowest Kp Distance } \\
\text { (ETS) }\end{array}$} & \multicolumn{5}{|c|}{$\begin{array}{c}\text { Lowest Kp } \\
\text { Distance (psbA-trnH) }\end{array}$} \\
\hline & Species Match & Value & Species Match & Value & Species Match & Value & & Species & $\operatorname{atch}(e$ & & Value \\
\hline B. pa. & B. pa & 0.000 & B. il & 0.000 & B. pa & 0.003 & B. pa & B. il & B. re & B. $s p$ & 0.004 \\
\hline B. re & B. re & 0.000 & B. il & 0.001 & B. re & 0.001 & B. pa & B. il & B. re & & 0.000 \\
\hline B. $\mathrm{mi}$ & B. $\mathrm{mi}$ & 0.001 & B. $\mathrm{mi}$ & 0.000 & NA & & B. mi & & & & 0.000 \\
\hline B. pu & B. pu & 0.006 & B. pu & 0.000 & NA & & B. pu & & & & 0.000 \\
\hline B. $s p$ & B. $\mathrm{sp}$ & 0.000 & B. il & 0.004 & NA & & B. pa & B. il & B. re & & 0.000 \\
\hline
\end{tabular}

A KP2 distance of 0.000 represents a $100 \%$ identity match of a sample with a species. Authenticated samples B. mi: B. microdonta (GH1599), B. pa: B. pauciflosculosa (GH1558), B. il: B. illinita (GH1586), B. pu: B. punctulata (GH1892), B. re: B. reticularioides (GH1426), B. sp: B. sphenophylla (GH1438), NA: not analyzed due to low sequence quality.

The samples analyzed were morphologically identified. The ITS sequences of samples B. pauciflosculosa, B. reticularioides, B. sphenophylla, and the trnL-trnF sequences of samples B. microdonta and B. punctulata support the species identification based on morphology as the sequences $100 \%$ matched the sequences from previously authenticated samples.

Only single sequences of authenticated samples were available for the sequence alignments. To achieve a more reliable way of sample identification based on genomic regions, more authenticated samples should be analyzed to get a better representation of the intraspecific sequence variations of a certain species.

\section{Materials and Methods}

\subsection{Plant Material}

Fresh samples of vegetative aerial parts were collected, in triplicate, from B. microdonta, B. pauciflosculosa, B. punctulata, B. reticularioides, and B. sphenophylla in March 2016 from open and sunny habitats in Campos Gerais, Ponta Grossa, Paraná, Southern Brazil (coordinates $25^{\circ} 5^{\prime} 11^{\prime \prime} \mathrm{S}$ and $50^{\circ} 6^{\prime} 23^{\prime \prime} \mathrm{W}$ ). The specimens were registered as ECT0000644 (B. microdonta), ECT0000641 (B. pauciflosculosa), ECT0000645 (B. punctulata), ECT0000642 (B. reticularioides), and ECT0000647 (B. sphenophylla), and deposited in the Herbarium of Embrapa Clima Temperado (ECT) in Rio Grande do Sul, Brazil. The access to the botanical material was authorized and licensed by the Conselho de Gestão do Patrimônio Genético (CGEN/SISGEN) registered under number A429DA6. The collected plant materials were selected and standardized in order to obtain leaves and stems with the same pattern. Then, the materials were dried in the shade at room temperature and cut into small pieces $(\sim 1 \mathrm{~cm})$.

\subsection{Extraction of Essential Oil (EO)}

Dried plant material (100 g) was subjected to hydrodistillation for $3 \mathrm{~h}$, in triplicate, using a Clevenger-type apparatus for the extraction of EOs. The EOs obtained were dried using anhydrous $\mathrm{Na}_{2} \mathrm{SO}_{4}$, stored in glass vials with Teflon-sealed caps, and kept under $-4 \pm 0.5^{\circ} \mathrm{C}$ with no light until analysis. The yield of EO was calculated in volume/mass \% [51]. 


\subsection{Chemicals}

GC-grade $n$-hexane $(>99 \%)$ was purchased from Sigma Aldrich (St. Louis, MO, USA). The reference standards of $\alpha$-pinene, $\beta$-pinene, camphene, sabinene, $\alpha$-thujone, $\beta$-myrcene, $p$-cymene, limonene, $\gamma$-terpinene, $\alpha$-terpineol, terpinolene, trans-pinocarveol, terpinen-4-ol, verbenone, $\beta$-elemene, carveol, bornyl acetate, caryophyllene oxide, viridiflorol, $\alpha$-bisabolol, and myrtenal were also purchased from Sigma-Aldrich.

Kongol (Figure S1) and spathulenol (Figure S2) were isolated from EO of B. microdonta and identified by NMR spectroscopy in the present study. Briefly, $180 \mathrm{mg}$ of EO of B. microdonta was subjected to a Biotage ZIP KP-SIL 45-g cartridge, and the isolation was performed on a Biotage Isolera $^{\mathrm{TM}}$ system (Biotage, Charlotte, NC). Hexanes-ethyl acetate was used for eluting with increasing proportions of ethyl acetate from $0 \%$ to $20 \%$. The eluted fractions ( $12 \mathrm{~mL}$ each) were collected and detected by using thin layer chromatography. Kongol $(23.8 \mathrm{mg})$ and spathulenol $(25.3 \mathrm{mg})$ were obtained from the fractions 102-106 and 95-99, respectively. The proton and carbon NMR spectra of the two isolates were recorded using an Agilent DD2-500 NMR spectrometer (Agilent, Santa Clara, CA) equipped with a One NMR probe operating at $499.79 \mathrm{MHz}$ for ${ }^{1} \mathrm{H}$ and $125.67 \mathrm{MHz}$ for ${ }^{13} \mathrm{C}$. The spectrum of spathulenol was identical to that of the reference standard. The spectral data of isolated kongol was also in agreement with that reported in the literature [52].

\subsection{Gas Chromatography-Mass Spectrometry (GC/MS) Analysis}

The EOs of B. microdonta, B. pauciflosculosa, B. punctulata, B. reticularioides, and B. sphenophylla were analyzed by GC/MS using an Agilent 7890A GC system equipped with a 5975C quadrupole mass spectrometer and a 7693 autosampler (Agilent Technologies, Santa Clara, CA, USA). Ten microliters of EOs were dissolved in $1 \mathrm{~mL}$ of $n$-hexane for each oil sample, and $1 \mu \mathrm{L}$ of the sample solution was injected. Helium was used as the carrier gas at a flow rate of $1 \mathrm{~mL} / \mathrm{min}$. The inlet temperature was set to $250{ }^{\circ} \mathrm{C}$ with a split injection mode for a split ratio of 50:1. Separation was performed on two columns with different polarity, non-polar DB-5MS (column 1) and polar DB-WAX (column 2) capillary columns (Agilent J\&W Scientific, Folsom, CA, USA) with the same dimensions of $30 \mathrm{~m} \times 0.25 \mathrm{~mm}$ i.d. $\times 0.25 \mu \mathrm{m}$ film thickness. The oven temperature program was as follows: (1) Column 1: the initial temperature was $45^{\circ} \mathrm{C}$ (held for $2 \mathrm{~min}$ ); it then increased to $130{ }^{\circ} \mathrm{C}$ at a rate of $2{ }^{\circ} \mathrm{C} / \mathrm{min}$ (held for $10 \mathrm{~min}$ ), to $150^{\circ} \mathrm{C}$ at a rate of $2{ }^{\circ} \mathrm{C} / \mathrm{min}$, and finally to $250{ }^{\circ} \mathrm{C}$ at a rate of $2{ }^{\circ} \mathrm{C} / \mathrm{min}$ and isothermal for $10 \mathrm{~min}$ at $280^{\circ} \mathrm{C}$ with a total experiment time of $70 \mathrm{~min}$; (2) Column 2: the initial temperature was $40{ }^{\circ} \mathrm{C}$ (held for $4 \mathrm{~min}$ ); it then increased to $200{ }^{\circ} \mathrm{C}$ at a rate of $3{ }^{\circ} \mathrm{C} / \mathrm{min}$, and to $240{ }^{\circ} \mathrm{C}$ at a rate of $20^{\circ} \mathrm{C} / \mathrm{min}$. Triplicate injections were made for each sample.

Mass spectra were recorded at $70 \mathrm{eV}$ at a scan mode from $m / z 35$ to 500 . The transfer line temperature was $260{ }^{\circ} \mathrm{C}$. The ion source and quadrupole temperatures were $230{ }^{\circ} \mathrm{C}$ and $130{ }^{\circ} \mathrm{C}$, respectively. Data acquisition was performed with Agilent MSD Chemstation (F.01.03.2357).

Compound identification involved the comparison of the mass spectra with the databases (Wiley and the National Institute of Standards and Technology (NIST) using a probability-based matching algorithm. Further identification was based on the relative retention indices compared with the literature [38] and the reference standards purchased from commercial sources or isolated in-house.

The raw percentage from the peak area of each compound was obtained in full-scan GC/MS analyses (DB-5MS and DB-WAX columns). Further standardization was not carried out, since our aim was focused on identifying the essential oil compounds for species differentiation.

\subsection{Antimalarial Activity}

The antimalarial activity of EOs from Baccharis species was determined using a colorimetric assay based on plasmodial lactate dehydrogenase (LDH) activity as described by Kumar et al. [53]. A suspension of red blood cells infected with D6 or W2 strains of P. falciparum was added to the wells of a 96-well plate containing test samples diluted in medium at several concentrations. Parasitic LDH 
activity was determined according to the method described by Makler and Hinrichs [54]. Chloroquine and artemisinin were included as the drug controls. $\mathrm{IC}_{50}$ values were calculated from the dose-response curves using Excelfit ${ }^{\circledR}$. DMSO (0.25\%) was used as the vehicle control. For calculating the selectivity index of the antimalarial activity of EOs, their toxicity to Vero cells (monkey kidney fibroblasts) was also determined. Essential oils at different concentrations were added, and plates were again incubated for $48 \mathrm{~h}$. The number of viable cells was determined using a vital dye (WST-8). Doxorubicin was used as a positive control.

\subsection{Antitrypanosomal Activity}

The screening that was employed to test the antitrypanosomal activity of the EOs of Baccharis species against T. brucei was detailed in a previous paper by Jain et al. [55]. Briefly, the samples were tested against trypomastigotes cultures of T. brucei. The cell cultures of T. brucei were treated with varying concentrations of the samples, and the growth of the parasite cells were monitored with Alamar blue assay. The results were analyzed with ExcelFit ${ }^{\circledR}$ to determine the $\mathrm{IC}_{50}$ and $\mathrm{IC}_{90}$ values.

\subsection{Insecticidal Studies against Bed Bugs}

The bed bug strains (Bayonne 'Insecticide resistant' and Ft. Dix 'Susceptible') were provided by Dr. Changlu Wang, Department of Entomology, Rutgers University, New Brunswick, NJ, and their colony was raised as explained by Montes et al. [56] using blood feeders (CG-1836-75 ChemGlass). The insecticidal activity of EOs against bed bugs was evaluated by fumigation, topical application, and residual studies. For fumigation test, the bed bugs were subjected to vapor toxicity in $125-\mathrm{mL}$ clear glass jars using two microliter aliquots of $125 \mu \mathrm{g} / \mu \mathrm{L}$ EO stock solution that was injected directly onto inner bottle wall $\sim 4 \mathrm{~cm}$ from the bottom. The jars were covered immediately with a screw cap and then sealed with parafilm ' $M$ '. The jars were then placed in the growth chamber, and data for mortality was recorded $24 \mathrm{~h}$ after treatment. Solutions were made in acetone, and the control treatment received acetone only. 2,2-Diclorovinil-dimetilfosfato (DDVP) was used as the standard.

Studies in topical application were performed with adult bugs, which were separated in the Petri dishes and anesthetized with $\mathrm{CO}_{2}$. Using a hand-held repeating dispenser, $1 \mu \mathrm{L}$ of treatment solution $(50 \mu \mathrm{g} / \mathrm{bug})$ in acetone was delivered onto the dorsal surface of the abdomen. Control bugs received $1 \mu \mathrm{L}$ of acetone alone. Data for the mortality of the bed bugs was recorded for seven days after treatment. There were three replicates with 10 bugs (mixed sex)/replicate. Deltamethrin was used as the standard (2.4 ng/bug).

For residual studies, the method described by Campbell and Miller [57] was used with minor modifications. A $100-\mu \mathrm{L}$ aliquot of treatment (diluted in acetone) was applied on $20-\mathrm{cm}^{2}$ Whatman \#1 filter paper achieving $100 \mu \mathrm{g} / \mathrm{cm}^{2}$ of residues. The treated filter papers were then placed in the Petri dish. Control treatments received only acetone. Ten adult bugs were released on the filter paper and mortality was recorded as mentioned in topical application. Deltamethrin was used as standard. Data of insecticidal investigations were analyzed for means, standard error, and one-way ANOVA in JMP 10.0.

\subsection{Microscopic Procedure}

The methods employed for light and scanning electron microscopy analysis of leaves and stems of Baccharis species are fully detailed in a previous paper by Budel et al. [4].

\subsection{DNA Extraction, PCR, Sequencing}

To extract genomic DNA from Baccharis, $100 \mathrm{mg}$ of freeze-dried leaves were ground to fine powder. Genomic DNA from Baccharis samples was extracted using the DNeasy Plant Mini Kit (Qiagen Inc., Valencia, Spain). Four genomic regions-namely ITS, ETS, $p s b \mathrm{~A}-\mathrm{t} r n \mathrm{H}$, and $t r n \mathrm{~L}-\mathrm{trnF}$-were amplified in $25-\mu \mathrm{L}$ reactions. 
The PCR consisted of a $25-\mu \mathrm{L}$ reaction mixture containing $2 \mu \mathrm{L}$ of the DNA solution, $1 \mathrm{x}$ PCR reaction buffer, $0.2 \mathrm{mM}$ of dNTP mixture, $0.2 \mu \mathrm{M}$ of each forward and reverse primers (Table 5), $1.5 \mathrm{mM}$ of $\mathrm{MgCl}_{2}$ and $1 \mathrm{U}$ of Platinum Taq DNA Polymerase (Invitrogen, Carlsbad, CA, USA). The program comprised of one initial denaturation step at $94^{\circ} \mathrm{C}$ for $3 \mathrm{~min}$, followed by 35 cycles at $94{ }^{\circ} \mathrm{C}$ for $30 \mathrm{~s}$, $\mathrm{X}{ }^{\circ} \mathrm{C}$ for $30 \mathrm{~s}$, and $72{ }^{\circ} \mathrm{C}$ for $\mathrm{Xs}$ (see Table 5 for annealing temperature and extension time).

Table 5. List of primers, $\mathrm{T}_{\mathrm{M}}$, and extension time.

\begin{tabular}{|c|c|c|c|c|}
\hline Genomic Regions & Sequence in $5^{\prime}-3^{\prime}$ & Source & $\mathrm{T}_{\mathrm{M}}$ & $\begin{array}{l}\text { Extension Time } \\
\quad \text { at } 72{ }^{\circ} \mathrm{C}\end{array}$ \\
\hline $\begin{array}{l}\text { ETS1f } \\
18 S-2 L\end{array}$ & $\begin{array}{l}\text { CTTTTTGTGCATAATGTATATATAGGGGG } \\
\text { TGACTACTGGCAGGATCAACCAG }\end{array}$ & Linder et al. [58] & $45^{\circ} \mathrm{C}$ & $60 \mathrm{~s}$ \\
\hline $\begin{array}{l}\text { ITS4 } \\
\text { ITS5 }\end{array}$ & $\begin{array}{l}\text { TCCTCCGCTTATTGATATGC } \\
\text { GGAAGTAAAAGTCGTAACAAGG }\end{array}$ & White et al. [59] & $52{ }^{\circ} \mathrm{C}$ & $30 \mathrm{~s}$ \\
\hline $\begin{array}{l}\operatorname{trnL}-F-\operatorname{trn} C \\
\operatorname{trnL}-F-\operatorname{trn} F\end{array}$ & $\begin{array}{l}\text { CGAAATCGGTAGACGCTACG } \\
\text { ATTTGAACTGGTGACACGAG }\end{array}$ & Taberlet et al. [60] & $52^{\circ} \mathrm{C}$ & $60 \mathrm{~s}$ \\
\hline $\begin{array}{l}\text { psbA } \\
\text { trnH (GUG) }\end{array}$ & $\begin{array}{l}\text { CGAAGCTCCATCTACAAATGG } \\
\text { ACTGCCTTGATCCACTTGGC }\end{array}$ & Hamilton et al. [61] & $56^{\circ} \mathrm{C}$ & $30 \mathrm{~s}$ \\
\hline
\end{tabular}

$\mathrm{T}_{\mathrm{M}}=$ Melting temperature.

After amplification, each PCR reaction was analyzed by electrophoresis on a 1.5\% borate agarose gel and visualized under UV light. The sizes of the PCR products were compared to the molecular size standard 1 kb plus DNA ladder (cat no.: 10787-018, Invitrogen, Carlsbad, CA, USA).

Successfully amplified PCR products were isolated with NucleoSpin ${ }^{\circledR}$ Gel and a PCR Clean-up kit (MACHEREY-NAGEL, cat no. 740609.50) and eluted with $30 \mu \mathrm{L}$ of Buffer AE from the DNeasy Plant Mini Kit (Qiagen Inc., Valencia, Spain). PCR products were sequenced in both directions at GeneWiz (South Plainfield, NJ, USA). Sequences were analyzed with DNASTAR (DNASTAR, Madison, WI, USA) and Clone manager 9 (Scientific and Educational Software, Cary, NC, USA) and visually inspected. Contiguous sequences were screened against previously sequenced authenticated samples.

\section{Conclusions}

In the present work, profiles of EOs from five species of Baccharis were analyzed and compared. The chemical compositions of EOs of B. pauciflosculosa, B. reticularioides, and B. sphenophylla are reported for the first time. Although the qualitative compositions of the EOs of these species were more or less similar, they showed distinctive differences in the quantity of the components. Some compounds were unique to these species, and hence can be used as chemical markers for species identification and authentication. B. microdonta differed from the other species by having kongol and spathulenol in high concentrations. B. pauciflosculosa showed $\beta$-pinene and limonene as major compounds. $\alpha$-Bisabolol was found only in B. punctulata. B. reticularioides showed $\alpha$-pinene, while B. sphenophylla presented $\alpha$-pinene, $\beta$-pinene, limonene, and spathulenol as major compounds.

B. microdonta and B. punctulata exhibited cytotoxicity, whereas B. pauciflosculosa, B. reticularioides, and B. sphenophylla showed moderate antimalarial activities. Only B. sphenophylla EO showed strong toxicity to bed bug viz., and $66.67 \%$ and $83.33 \%$ mortality in 'Bayonne' and 'Ft.Dix' in the fumigation bioassay. B. pauciflosculosa and B. reticularioides showed good antitrypanosomal activities.

The leaves and stems of all five Baccharis species possessed glandular trichomes and ducts as secretory structures. All three types of glandular trichomes that were observed in this study contained EOs. DNA barcoding using ITS and trnL-trnF sequences were useful for the authentication of the studied Baccharis species.

Supplementary Materials: The supplementary materials are available online, Figure S1: Proton and Carbon NMR spectra of kongol, Figure S2: Proton and Carbon NMR spectra of spathulenol. 
Author Contributions: Collection of plant materials, I.J.M.T., P.V.F. and J.M.B.; Identification of plant materials, G.H.; Extraction of EOs, L.M.M. and J.M.B.; Microscopy analyses, J.M.B. and V.R.; Chemical profile, J.M.B., M.W. and J.Z.; DNA barcoding, N.T.; Antimalarial activity, S.I.K.; Antitrypanosomal activity, B.T.; Insecticidal activity, J.U.R.; Supervision of the laboratory work, I.A.K.

Funding: This research was funded by CAPES-Coordenação de Aperfeiçoamento de Pessoal de Nível Superior, scholarship number (88881.119611/2016-01) and UEPG-Universidade Estadual de Ponta Grossa. The bed bug research was supported by USDA-Discovery \& Development of Natural Products based insect management for medical, veterinary \& Urban (58-6066-6-043).

Conflicts of Interest: The authors declare no conflict of interests.

\section{References}

1. Heiden, G.; Schneider, A. Baccharis. In Lista de Espécies da Flora do Brasil; Jardim Botânico do Rio de Janeiro: Rio de Janeiro, Brazil, 2015.

2. Budel, J.M.; Matzenbacher, N.I.; Duarte, M.R. Genus Baccharis (Asteraceae): A Review of Chemical and Pharmacological Studies; Studium Press LLC: Houston, TX, USA, 2008; pp. 1-18.

3. Ramos Campos, F.; Bressan, J.; Godoy Jasinski, V.C.; Zuccolotto, T.; da Silva, L.E.; Bonancio Cerqueira, L. Baccharis (Asteraceae): Chemical Constituents and Biological Activities. Chem. Biodivers. 2016, 13, 1-17. [CrossRef] [PubMed]

4. Budel, J.M.; Raman, V.; Monteiro, L.M.; Almeida, V.P.; Bobek, V.B.; Heiden, G.; Takeda, I.J.M.; Khan, I.A. Foliar anatomy and microscopy of six Brazilian species of Baccharis (Asteraceae). Microsc. Res. Tech. 2018. [CrossRef] [PubMed]

5. Abad, M.J.; Bermejo, P. Baccharis (Compositae): A review update. Arkivoc 2007, 7, 76-96.

6. Simões-Pires, C.A.; Debenedetti, S.; Spegazzini, E.; Mentz, L.A.; Matzenbacher, N.I.; Limberger, R.P.; Henriques, A.T. Investigation of the essential oil from eight species of Baccharis belonging to sect. Caulopterae (Asteraceae, Astereae): A taxonomic approach. Plant Syst. Evol. 2005, 253, 23-32. [CrossRef]

7. Budel, J.M.; Duarte, M.R.; Döll-Boscardin, P.M.; Farago, P.V.; Matzenbacher, N.I.; Sartoratto, A.; Sales Maia, B.H.L.N. Composition of essential oils and secretory structures of Baccharis anomala, B. megapotamica and B. ochracea. J. Essent. Oil Res. 2012, 24, 19-24. [CrossRef]

8. Retta, D.; Gattuso, M.; Gattuso, S.; Di Leo Lira, P.; van Baren, C.; Bandoni, A. Volatile constituents of five Baccharis Species from Northeastern Argentina. J. Braz. Chem. Soc. 2009, 20, 1379-1384. [CrossRef]

9. Negreiros, M.O.; Pawlowski, Â.; Zini, C.A.; Soares, G.L.G.; Motta, A.S.; Frazzon, A.P.G. Antimicrobial and antibiofilm activity of Baccharis psiadioides essential oil against antibiotic-resistant Enterococcus faecalis strains. Pharm. Biol. 2016, 54, 3272-3279. [CrossRef] [PubMed]

10. Perera, W.H.; Bizzo, H.R.; Gama, P.E.; Alviano, C.S.; Salimena, F.R.G.; Alviano, D.S.; Leitão, S.G. Essential oil constituents from high altitude Brazilian species with antimicrobial activity: Baccharis parvidentata Malag., Hyptis monticola Mart. ex Benth. and Lippia origanoides Kunth. J. Essent. Oil Res. 2017, 29, 109-116. [CrossRef]

11. Florão, A.; Budel, J.M.; Duarte, M.R.; Marcondes, A.; Rodrigues, R.A.F.; Rodrigues, M.V.N.; Santos, C.A.M.; Weffort-Santos, A.M. Essential oils from Baccharis species (Asteraceae) have anti-inflammatory effects for human cells. J. Essent. Oil Res. 2012, 24, 561-570. [CrossRef]

12. Valarezo, E.; Rosales, J.; Morocho, V.; Cartuche, L.; Guaya, D.; Ojeda-Riascos, S.; Armijos, C.; González, S. Chemical composition and biological activity of the essential oil of Baccharis obtusifolia Kunth from Loja, Ecuador. J. Essent. Oil Res. 2015, 27, 212-216. [CrossRef]

13. Sobrinho, A.C.N.; de Souza, E.B.; Rocha, M.F.G.; Albuquerque, M.R.J.R.; Bandeira, P.N.; dos Santos, H.S.; de Paula Cavalcante, C.S.; Oliveira, S.S.; Aragão, P.R.; de Morais, S.M.; et al. Chemical composition, antioxidant, antifungal and hemolytic activities of essential oil from Baccharis trinervis (Lam.) Pers. (Asteraceae). Ind. Crops Prod. 2016, 84, 108-115. [CrossRef]

14. De Oliveira, R.N.; Rehder, V.L.; Santos Oliveira, A.S.; Junior, I.M.; de Carvalho, J.E.; de Ruiz, A.L.; Jeraldo Vde, L.; Linhares, A.X.; Allegretti, S.M. Schistosoma mansoni: In vitro schistosomicidal activity of essential oil of Baccharis trimera (less) DC. Exp. Parasitol. 2012, 132, 135-143. [CrossRef] [PubMed]

15. Botas, G.; Cruz, R.; de Almeida, F.; Duarte, J.; Araújo, R.; Souto, R.; Ferreira, R.; Carvalho, J.; Santos, M.; Rocha, L.; et al. Baccharis reticularia DC. and Limonene Nanoemulsions: Promising Larvicidal Agents for Aedes aegypti (Diptera: Culicidae) Control. Molecules 2017, 22, 1990. [CrossRef] [PubMed] 
16. Pereira, C.B.; Kanunfre, C.C.; Farago, P.V.; Borsato, D.M.; Budel, J.M.; de Noronha Sales Maia, B.H.L.; Campesatto, E.A.; Sartoratto, A.; Miguel, M.D.; Miguel, O.G. Cytotoxic mechanism of Baccharis milleflora (Less.) DC. essential oil. Toxicol. In Vitro 2017, 42, 214-221. [CrossRef] [PubMed]

17. Perez, C.; Anesini, C. Inhibition of Pseudomonas aeruginosa by Argentinean medicinal plants. Fitoterapia 1994, 65, 169-172.

18. Soares, V.C.G.; Bristot, D.; Pires, C.L.; Toyama, M.H.; Romoff, P.; Pena, M.J.; Favero, O.A.; Toyama, D.O. Evaluation of Extracts and Partitions from Aerial Parts of Baccharis microdonta on Enzymatic Activity, Pro-Inflammatory and Myotoxic Activities Induced by Secretory Phospholipase A2 from Bothrops jararacussu. Toxicon 2012, 60, 208-208. [CrossRef]

19. Anesini, C.; Perez, C. Screening of plants used in Argentine folk medicine for antimicrobial activity. J. Ethnopharmacol. 1993, 39, 119-128. [CrossRef]

20. Budel, J.M.; Wang, M.; Raman, V.; Zhao, J.; Khan, S.I.; Rehman, J.U.; Monteiro, L.M.; Heiden, G.; Farago, P.V.; Khan, I.A. Chemical Composition of Essential oils, biological activity and secretory structures of species of Baccharis from Brazil. In Proceedings of the American Society of Pharmacognosy Annual Meeting, Lexington, KY, USA, 21-25 July 2018; pp. 78-79.

21. Malizia, R.A.; Cardell, D.A.; Molli, J.S.; González, S.; Guerra, P.E.; Grau, R.J. Volatile Constituents of Leaf Oils from the Genus Baccharis. Part II: Baccharis obovata Hooker et Arnott and B. salicifolia (Ruiz et Pav.) Pers. Species from Argentina. J. Essent. Oil Res. 2005, 17, 194-197. [CrossRef]

22. Lago, J.H.G.; Romoff, P.; Fávero, O.A.; Soares, M.G.; Baraldi, P.T.; Corrêa, A.G.; Souza, F.O. Composição química dos óleos essenciais das folhas de seis espécies do gênero Baccharis de "Campos de Altitude" da mata atlântica paulista. Quím. Nov. 2008, 31, 727-730. [CrossRef]

23. Schossler, P.; Schneider, G.L.; Wunsch, D.; Soares, G.L.G.; Zini, C.A. Volatile compounds of Baccharis punctulata, Baccharis dracunculifolia and Eupatorium laevigatum obtained using solid phase microextraction and hydrodistillation. J. Braz. Chem. Soc. 2009, 20, 277-287. [CrossRef]

24. Gobbo-Neto, L.; Lopes, N.P. Plantas medicinais: Fatores de influência no conteúdo de metabólitos secundários. Quím. Nov. 2007, 30, 374-381. [CrossRef]

25. Tischer, B.; Vendruscolo, R.G.; Wagner, R.; Menezes, C.R.; Barin, C.S.; Giacomelli, S.R.; Budel, J.M.; Barin, J.S. Effect of grinding method on the analysis of essential oil from Baccharis articulata (Lam.) Pers. Chem. Pap. 2017, 71, 753-761. [CrossRef]

26. Sayuri, V.A.; Romoff, P.; Fávero, O.A.; Ferreira, M.J.P.; Lago, J.H.G.; Buturi, F.O.S. Chemical Composition, Seasonal Variation, and Biosynthetic Considerations of Essential Oils from Baccharis microdonta and $B$. elaeagnoides (Asteraceae). Chem. Biodivers. 2010, 7, 2771-2782. [CrossRef] [PubMed]

27. Saulle, C.C.; Raman, V.; Oliveira, A.V.G.; Maia, B.H.L.N.S.; Meneghetti, E.K.; Flores, T.B.; Farago, P.V.; Khan, I.A.; Budel, J.M. Anatomy and volatile oil chemistry of Eucalyptus saligna cultivated in South Brazil. Rev. Bras. Farmacogn. 2018, 28, 125-134. [CrossRef]

28. Raut, J.S.; Karuppayil, S.M. A status review on the medicinal properties of essential oils. Ind. Crops Prod. 2014, 62, 250-264. [CrossRef]

29. Guimarães, A.G.; Oliveira, A.P.; Ribeiro, E.A.N.; Claudino, F.S.; Almeida, J.R.G.S.; Lima, J.T.; Bonjardin, L.R.; Ribeiro, L.A.A.; Quintas-Júnior, L.J.; Santos, M.R.V. Atividade farmacológica de monoterpenos. In Farmacognosia: Coletânea Científica; Souza, G.H.B., Mello, J.C.P., Lopes, N.P., Eds.; UFOP: Ouro Preto, Brazil, 2012; pp. 219-250.

30. Bogo, C.A.; de Andrade, M.H.; de Paula, J.P.; Farago, P.V.; Döll-Boscardin, P.M.; Budel, J.M. Comparative analysis of essential oils of Baccharis L.: A review. Revis. Strict. Sensu 2016, 1, 1-11. [CrossRef]

31. Xavier, V.B.; Vargas, R.M.F.; Minteguiaga, M.; Umpiérrez, N.; Dellacassa, E.; Cassel, E. Evaluation of the key odorants of Baccharis anomala DC. essential oil: New applications for known products. Ind. Crops Prod. 2013, 49, 492-496. [CrossRef]

32. De Assis Lage, T.C.; Montanari, R.M.; Fernandes, S.A.; de Oliveira Monteiro, C.M.; de Oliveira Souza Senra, T.; Zeringota, V.; da Silva Matos, R.; Daemon, E. Chemical composition and acaricidal activity of the essential oil of Baccharis dracunculifolia De Candole (1836) and its constituents nerolidol and limonene on larvae and engorged females of Rhipicephalus microplus (Acari: Ixodidae). Exp. Parasitol. 2015, 148, 24-29. [CrossRef] [PubMed] 
33. Minteguiaga, M.; Umpiérrez, N.; Xavier, V.; Lucas, A.; Mondin, C.; Fariña, L.; Cassel, E.; Dellacassa, E. Recent Findings in the Chemistry of Odorants from Four Baccharis Species and Their Impact as Chemical Markers. Chem. Biodivers. 2015, 12, 1339-1348. [CrossRef] [PubMed]

34. Kurdelas, R.R.; López, S.; Lima, B.; Feresin, G.E.; Zygadlo, J.; Zacchino, S.; López, M.L.; Tapia, A.; Freile, M.L. Chemical composition, anti-insect and antimicrobial activity of Baccharis darwinii essential oil from Argentina, Patagonia. Ind. Crops Prod. 2012, 40, 261-267. [CrossRef]

35. Minteguiaga, M.; Mercado, M.I.; Ponessa, G.I.; Catalán, C.A.N.; Dellacassa, E. Morphoanatomy and essential oil analysis of Baccharis trimera (Less.) DC. (Asteraceae) from Uruguay. Ind. Crops Prod. 2018, 112, 488-498. [CrossRef]

36. Minteguiaga, M.; González, A.; Cassel, E.; Umpierrez, N.; Fariña, L.; Dellacassa, E. Volatile Constituents from Baccharis spp. L. (Asteraceae): Chemical Support for the Conservation of Threatened Species in Uruguay. Chem. Biodivers. 2018, 15, e1800017. [CrossRef] [PubMed]

37. Adams, R.P. Identification of Essential Oil Components by Gas Chromatography/Mass Spectroscopy, 4th ed.; Allured Publishing Corporation: Carol Stream, IL, USA, 2007.

38. Davies, N. Gas chromatographic retention indices of monoterpenes and sesquiterpenes on methyl silicon and Carbowax 20M phases. J. Chromatogr. A 1990, 503, 1-24. [CrossRef]

39. Da Silva Filho, A.A.; Resende, D.O.; Fukui, M.J.; Santos, F.F.; Pauletti, P.M.; Cunha, W.R.; Silva, M.L.; Gregorio, L.E.; Bastos, J.K.; Nanayakkara, N.P. In vitro antileishmanial, antiplasmodial and cytotoxic activities of phenolics and triterpenoids from Baccharis dracunculifolia DC. (Asteraceae). Fitoterapia 2009, 80, 478-482. [CrossRef] [PubMed]

40. Munoz, V.; Sauvain, M.; Bourdy, G.; Arrazola, S.; Callapa, J.; Ruiz, G.; Choque, J.; Deharo, E. A search for natural bioactive compounds in Bolivia through a multidisciplinary approach. Part III. Evaluation Of the antimalarial activity of plants used by Altenos Indians. J. Ethnopharmacol. 2000, 71, 123-131. [CrossRef]

41. Kpoviessi, S.; Bero, J.; Agbani, P.; Gbaguidi, F.; Kpadonou-Kpoviessi, B.; Sinsin, B.; Accrombessi, G.; Frederich, M.; Moudachirou, M.; Quetin-Leclercq, J. Chemical composition, cytotoxicity and in vitro antitrypanosomal and antiplasmodial activity of the essential oils of four Cymbopogon species from Benin. J. Ethnopharmacol. 2014, 151, 652-659. [CrossRef] [PubMed]

42. Costa, S.; Cavadas, C.; Cavaleiro, C.; Salgueiro, L.; do Céu Sousa, M. In vitro susceptibility of Trypanosoma brucei brucei to selected essential oils and their major components. Exp. Parasitol. 2018, 190, 34-40. [CrossRef] [PubMed]

43. Viegas Júnior, C. Terpenos com atividade inseticida: Uma alternativa para o controle químico de insetos. Quim. Nov. 2003, 26, 390-400. [CrossRef]

44. Maia, M.F.; Moore, S.J. Plant-based insect repellents: A review of their efficacy, development and testing. Malar. J. 2011, 10, S11. [CrossRef] [PubMed]

45. Lima, R.K.; Cardoso, M.G.; Moraes, J.C.; Carvalho, S.M.; Rodrigues, V.G.; Guimarães, L.G.L. Chemical composition and fumigant effect of essentialoil of Lippia sidoides Cham. and monoterpenes against Tenebrio molitor L. (Coleoptera: Tenebrionidae). Ciênc. Agrotecnol. 2011, 35, 664-671. [CrossRef]

46. Gottlieb, O.; Salatino, A. Função e evolução de óleos essenciais e de suas estruturas secretoras. Ciênc. Cul. 1987, 39, 707-716.

47. Budel, J.M.; Paula, J.P.; Santos, V.L.P.; Franco, C.R.C.; Farago, P.V.; Duarte, M.R. Pharmacobotanical study of Baccharis pentaptera. Rev. Bras. Farmacogn. 2015, 25, 314-319. [CrossRef]

48. Bobek, V.B.; Heiden, G.; Oliveira, C.F.; Almeida, V.P.; Paula, J.P.; Farago, P.V.; Nakashima, T.; Budel, J.M. Comparative analytical micrographs of vassouras (Baccharis, Asteraceae). Rev. Bras. Farmacogn. 2016, 26, 665-672. [CrossRef]

49. Espinar, L.A. Las especies de Baccharis (Compositae) de Argentina Central. In Facultad de Ciencias Exactas, Fisicas y Naturales; Universidad Nacional de Córdoba: Córdoba, Argentina, 1974.

50. Techen, N.; Parveen, I.; Pan, Z.; Khan, I.A. DNA barcoding of medicinal plant material for identification. Curr. Opin. Biotechnol. 2014, 25, 103-110. [CrossRef] [PubMed]

51. ANVISA. Farmacopeia Brasileira; ANVISA (Agência Nacional de Vigilância Sanitária): Brasília, Brasil, 2010.

52. Kesselmans, R.P.W.; Wijnberg, J.B.P.A.; de Groot, A.; van Beek, T.A. Chromatographic and Spectroscopic Data of All Stereoisomers of Eudesm-11-en-4-ol. J. Essent. Oil Res. 1992, 4, 201-217. [CrossRef] 
53. Kumar, N.; Khan, S.I.; Beena; Rajalakshmi, G.; Kumaradhas, P.; Rawat, D.S. Synthesis, antimalarial activity and cytotoxicity of substituted 3,6-diphenyl-[1,2,4,5]tetraoxanes. Bioorg. Med. Chem. 2009, 17, 5632-5638. [CrossRef] [PubMed]

54. Makler, M.T.; Hinrichs, D.J. Measurement of the Lactate Dehydrogenase Activity of Plasmodium falciparum as an Assessment of Parasitemia. Am. J. Trop. Med. Hyg. 1993, 48, 205-210. [CrossRef] [PubMed]

55. Jain, S.; Jacob, M.; Walker, L.; Tekwani, B. Screening North American plant extracts in vitro against Trypanosoma brucei for discovery of new antitrypanosomal drug leads. BMC Complement. Altern. Med. 2016, 16, 131. [CrossRef] [PubMed]

56. Montes, C.; Cuadrillero, C.; Vilella, D. Maintenance of a laboratory colony of Cimex lectularius (Hemiptera: Cimicidae) using an artificial feeding technique. J. Med. Entomol. 2002, 39, 675-679. [CrossRef] [PubMed]

57. Campbell, B.; Miller, D. Insecticide Resistance in Eggs and First Instars of the Bed Bug, Cimex lectularius (Hemiptera: Cimicidae). Insects 2015, 6, 122-132. [CrossRef] [PubMed]

58. Linder, C.R.; Goertzen, L.R.; Heuvel, B.V.; Francisco-Ortega, J.; Jansen, R.K. The Complete External Transcribed Spacer of 18S26S-rDNA: Amplification and Phylogenetic Utility at Low Taxonomic Levels in Asteraceae and Closely Allied Families. Mol. Phylogenet Evol. 2000, 14, 285-303. [CrossRef] [PubMed]

59. White, T.J.; Bruns, T.; Lee, S.; Taylor, J. Amplification and direct sequencing of fungal ribosomal RNA genes for phylogenetics. In PCR Protocols; Innis, M.A., Gelfand, D.H., Sninsky, J.J., White, T.J., Eds.; Academic Press: San Diego, CA, USA, 1990; pp. 315-322.

60. Taberlet, P.; Gielly, L.; Pautou, G.; Bouvet, J. Universal primers for amplification of three non-coding regions of chloroplast DNA. Plant. Mol. Biol. 1991, 17, 1105-1109. [CrossRef] [PubMed]

61. Hamilton, M.B. Four primer pairs for the amplification of chloroplast intergenic regions with intraspecific variation. Mol. Ecol. 1999, 8, 521-523. [PubMed]

Sample Availability: Samples of the compounds are not available from the authors.

(C) 2018 by the authors. Licensee MDPI, Basel, Switzerland. This article is an open access article distributed under the terms and conditions of the Creative Commons Attribution (CC BY) license (http://creativecommons.org/licenses/by/4.0/). 